\title{
ANALISIS PENGARUH PENDIDIKAN DAN PELATIHAN TEKNIS SERTA MOTIVASI TERHADAP KINERJA ALUMNI BALAI PENDIDIKAN DAN PELATIHAN INDUSTRI REGIONAL I DI MEDAN
}

\author{
James Ronal Tambunan \\ AMIK Widya Loka Medan \\ Correspondent Email: jamesronaldtambunan@gmail.com
}

\begin{abstract}
Balai Diklat Industri Regional - I Medan us one of technical executive unitaries in education and training sector is responsible for center for Industrial Education and Training of the Ministry of Industry. Since Regulation number 22 year 1999 for local autonomy is legalized and then has been changed to regulation number 32 year 2003, there are many changes in the structure of organization including reposition and substitution of functionaries and officials in industrial service institution. Due to the reposition, there are many officials still do not have enough technical substantive knowledge about industry sector as their aquip to do their dutter. In order to repair this condition, technical training needs to be done. It aims to synchronize perception between the older and the newer ones. The purpose of this research is to look for and analyze the effect of Technical Training and motivation of alumnae's work in Balai Diklat Industri Regional I Medan. Hypothesis of the research is Technical Training and motivation affect alumnae's work in Balai Diklat Industri Regional I Medan. Method use in taking the samples is by using Slovin Formulation in which from 179 populations about 124 samples are taken. Hypothesis is tested by using compound linear regressive analysis. It is held by doing simultaneous test (f test) and partial Test (t test). Both of tests have purpose to know the effect of independent variable to dependent variable on relieance level $95 \%$ or $\alpha=0,005$. The result of analysis shows that Technical Training and motivation have simultaneous and significant effect to work motivation of alumnae in Balai Diklat Industri Regional I Medan. The significant level is 0.000 . Determinant Coefficient $\left(\mathrm{R}^{2}\right)$ of independent variable to dependent variable is about $59,3 \%$ and the rest $(40,7 \%)$ is affected by another variable that is not used in this research. The result of $t$ test (partial test) shows every independent variable used has significant effect to its dependent variable. Technical Training variable has real effect to the work with significant effect to the work 0.01 with significant level 0,000 smaller than $0,005(5 \%)$.
\end{abstract}

Keywords: Technical Training, Motivation and Work Motivation.

\section{PENDAHULUAN}

\section{I.1. Latar Belakang}

Setiap kegiatan yang dilakukan suatu organisasi tentu membutuhkan berbagai sumber daya, seperti modal, material, dan mesin. Sumber daya yang ada tidak akan berarti apabila tidak dikelola dengan baik, untuk mengelolanya dibutuhkan sumber daya manusia. Sumber daya manusia mempunyai peranan penting bagi organisasi, karena memiliki bakat, tenaga dan kreativitas yang sangat dibutuhkan untuk menggerakkan roda organisasi dalam upaya mencapai tujuan. 
Pada umumnya, tujuan setiap organisasi, baik organisasi publik maupun swasta, akan dapat tercapai dengan baik apabila pegawai dapat menjalankan tugas-tugasnya secara efektif dan efisien. Efektivitas dan efisiensi kerja dapat diperoleh melalui pendidikan dan pelatihan pegawai untuk meningkatkan kemampuan kerjanya. Dengan demikian, pengembangan pegawai merupakan upaya untuk memperbaiki efektivitas dan efisiensi kerja pegawai dalam mencapai hasil-hasil kerja yang telah ditetapkan. Perbaikan efektivitas dan efisiensi kerja itu dapat dilakukan dengan cara pendidikan dan pelatihan.

Kemampuan pegawai terhadap pelaksanaan tugas maupun pengetahuan umum yang mempengaruhi pelaksanaan tugas sangat menentukan keberhasilan dalam pelaksanaan tugas dengan baik. Pegawai yang kurang memiliki kemampuan yang cukup tentang bidang kerjanya akan bekerja tersendat-sendat. Selain itu terjadi pemborosan bahan, waktu, dan bahan produksi yang lain akan diperbuat oleh golongan pegawai yang belum memiliki pengetahuan yang cukup akan bidang kerjanya. Pemborosan-pemborosan tersebut akan mempertinggi biaya pencapaian tujuan organisasi. Oleh karena itu, pengetahuan pegawai harus diperbaiki dan dikembangkan agar pegawai tidak berbuat sesuatu yang merugikan usaha-usaha pencapaian tujuan organisasi atau perusahaan.

Sektor industri merupakan perusahaan yang diharapkan berkembang dalam arena persaingan sehingga menjadi motor penggerak perekonomian nasional pada masa kini dan masa depan. Oleh sebab itu, dibutuhkan potensi daya saing yang berkelanjutan, upaya pemanfaatan seluruh sumberdaya yang dimiliki dan juga memanfaatkan peluang-peluang yang ada di dalam maupun luar negeri secara optimal.

Sejak berlakunya Undang-Undang Nomor 22 Tahun 1999 tentang Otonomi Daerah yang kini telah diubah dengan Undang-Undang Nomor 32 Tahun 2003, banyak terjadi perubahan struktur organisasi termasuk penggantian para pejabat maupun staf di lingkungan Dinas Perindustrian. Sebagai dampaknya terjadi rotasi ataupun mutasi pegawai baik dari internal ataupun dari luar Dinas Perindustrian, sehingga banyak pegawai belum atau kurang memiliki pengetahuan substantif teknis industri sebagai bekal dalam melaksanakan tugasnya, di mana ini dirasakan sangat mempengaruhi terhadap kemampuan dan juga mempengaruhi motivasi dalam bekerja yang selanjutnya mempengaruhi kinerja dari pada instansi perindustrian yang ada di daerah. Selain itu perkembangan ilmu pengetahuan dan teknologi yang begitu cepat menuntut aparat pembina industri agar senantiasa mengikuti dan beradaptasi dengan perkembangan tersebut, maka pemerintah mengeluarkan Peraturan Pemerintah Nomor 101 Tahun 2000 tentang Pendidikan dan Pelatihan Pegawai Negeri Sipil.

Balai Diklat Industri Regional-I Medan sebagai salah satu unit pelaksana teknis di bidang pendidikan dan pelatihan yang berada di bawah dan bertanggung jawab kepada Pusat Pendidikan dan Pelatihan Industri Departemen Perindustrian, mempunyai tugas pokok dan fungsi penyelenggaraan pendidikan dan pelatihan bagi sumber daya manusia aparatur dan dunia usaha sektor industri, dituntut eksistensinya sebagai unit yang mandiri yang mampu mengidentifikasi dan menyikapi perubahan tersebut melalui penyelenggaraan berbagai program pendidikan dan pelatihan teknis sesuai dengan kebutuhan pasar dan sejalan dengan kebijakan pembangunan industri nasional serta kemampuan (core competence) daerah, untuk itu Balai Diklat Industri Regional-I Medan menyediakan program-program diklat teknis industri dan diklat fungsional bagi sumber daya manusia aparatur untuk memenuhi kebutuhan di atas sehingga tercipta aparat pembina industri yang profesional dan kompoten di bidangnya.

Diklat Teknis ini bertujuan untuk menyamakan persepsi antara pusat dan daerah dalam pelaksanaan pembinaan industri di daerah terutama ditujukan bagi pagawai yang mutasi. Adapun program pendidikan dan pelatihan teknis telah dilaksanakan oleh Balai Diklat Industri Regional-I Medan. Berikut ini adalah data pelaksanaan program diklat teknis serta jumlah pegawai yang telah mengikuti pendidikan dan pelatihan teknis Sistem Industri I.

Tabel I.1. Pelaksanaan Program Pendidikan dan Pelatihan Sistem Industri - I serta Jumlah Pegawai Dinas Perindustrian yang Mengikutinya Tahun 2006 - 2017 


\begin{tabular}{cccc}
\hline \multirow{2}{*}{ No } & Provinsi & Tahun & Jumlah Peserta \\
\hline 1 & NANGGROE ACEH DARUSSALAM & 2006 & 16 orang \\
& & 2007 & 17 orang \\
& & 2008 & 16 orang \\
\hline 2 & SUMATERA UTARA & 2006 & 24 orang \\
& & 2007 & 24 orang \\
& & 2008 & 24 orang \\
\hline 3 & RIAU & 2006 & 13 orang \\
& & 2007 & 13 orang \\
& & 2008 & 14 orang \\
\hline 4 & KEPULAUAN RIAU & 2006 & 6 orang \\
& & 2007 & 6 orang \\
\hline & & 2008 & 179 orang
\end{tabular}

Sumber: Balai Diklat Industri Medan Tahun 2018.

Adapun jumlah pelaksanaan program pendidikan dan pelatihan teknis berbanding terbalik dengan pertambahan atau perputaran mutasi pegawai.

Sekitar 60\% dari 66 Kepala Dinas Perindustrian yang berada di Wilayah Kerja Balai Diklat Industri Regional I Medan pada Rapat Koordinasi tahun 2005 sampai dengan 2018 mengeluhkan menurunnya kualitas kinerja para bawahannya, hal ini sangat mengecewakan. Pegawai tidak dapat menyelesaikan tugas dengan baik sesuai dengan target yang telah ditetapkan. Banyak waktu tersita hanya untuk memperbaiki kesalahan pekerjaan yang seharusnya tidak perlu terjadi. Tidak diberikannya pelatihan dan pendidikan teknis yang sesuai dengan kebutuhan pekerjaan pegawai, ini membuat motivasi para pegawai menjadi menurun.

Pegawai merupakan sumber daya manusia yang terlibat langsung dalam menjalankan kegiatan organisasi. Oleh sebab itu organisasi harus harus memberikan perhatian secara maksimal pada pegawainya, baik perhatian dari segi kualitas pengetahuan dan ketrampilan, sehingga motivasi para pegawai meningkat serta terdorong untuk memberikan segala kemampuannya sesuai yang dibutuhkan organisasi.

Para pegawai berharap agar pihak pimpinan lebih transparan dan objektif dalam memberikan penilaian kinerja pegawai, karena penilaian kinerja merupakan tolok ukur bagi instansi untuk mempromosikan pegawai yang bersangkutan. Ada satu masalah di mana seorang pegawai yang kurang berprestasi dalam melakukan pekerjaan memperoleh promosi yang sama dengan pegawai lain yang prestasinya cukup baik. Tentu pegawai yang mempunyai prestasi yang baik tersebut merasakan ketidakadilan atas tindakan tersebut.

\section{I.2. Perumusan Masalah}

Berdasarkan uraian dan latar belakang yang telah diuraikan sebelumnya, maka perumusan masalah dari penelitian ini adalah, apakah Diklat Teknis dan Motivasi berpengaruh terhadap kinerja alumni Balai Diklat Industri Regional I Medan?

\section{I.3. Kerangka Berpikir}

Perkembangan organisasi dari waktu ke waktu, baik dilihat dari sudut beban tugas, perkembangan teknologi, dan metode kerja yang baru, perlu mendapat perhatian dan respon dari organisasi. Oleh sebab itu, 
pemberdayaan pegawai yang akan diberi wewenang dan tanggung jawab, perlu dibekali dengan pengetahuan dan ketrampilan yang memadai. Pembekalan itu dapat dilakukan melalui pemberian pelatihan dan pendidikan yang berkaitan dengan tugas dan tanggung jawab yang akan diberikan kepada meraka.

Mathis and Jackson (2003) menyatakan bahwa:

"The three major factors that effect how agiven individual performs, the factors are: (1) Individual ability to do the work, (2) effort level expended, and (3) organizational support.

Individual performance is enhanced to the degree tgat all three components are present with an individual employee. However, performance is diminished if any of these factors is reduced or absent"

(Tiga faktor utama yang mempengaruhi bagaimana individu yang ada bekerja, faktor-faktor tersebut adalah: (1) kemampuan individual untuk melakukan pekerjaan tersebut (2) tingkat usaha yang dicurahkan, dan (3) dukungan organisasi.

Kinerja individual ditingkatkan sampai tingkat di mana ketiga komponen tersebut ada dalam karyawan. Akan tetapi, kinerja berkurang apabila salah satu faktor ini dikurangi atau tidak ada.

Pendidikan dan pelatihan merupakan proses untuk meningkatkan kompetensi pegawai yang dilakukan dalam waktu yang relatif singkat, baik untuk pegawai baru (yang baru mutasi) maupun pegawai lama. Hal ini senantiasa dilakukan organisasi dengan tujuan meningkatkan pengetahuan, ketrampilan dan kemampuan para pegawai secara terus-menerus.

Pendidikan dan pelatihan juga dimaksudkan untuk membantu pegawai dalam memahami suatu pengetahuan praktis yang dibutuhkan dalam menyelesaikan tugas, terutama tugas-tugas yang membutuhkan pengetahuan dan ketrampilan sejalan dengan perkembangan ilmu, teknologi dan peraturan yang berlaku, yang harus dikuasai oleh pegawai.

Simamora (2004) menyatakan bahwa, "Sebagai salah satu elemen penting untuk meningkatkan kinerja pegawai, pelatihan merupakan sarana untuk menciptakan suatu lingkungan di mana para pegawai dapat memperoleh atau mempelajari sikap, kemampuan serta keahlian pengetahuan dan perilaku spesifik yang berkaitan dengan pekerjaannya. Pelatihan yang efektif secara signifikan sangat berpengaruh terhadap peningkatan proses kerja, hal ini disebabkan karena kesalahan atau kekurangan dalam melaksanakan pekerjaan di masa silam, dapat dikoreksi. Untuk memperbaiki kemampuan kinerja pegawai dan mengoreksi kekurangan kinerja di masa silam, dapat dilakukan dengan cara meningkatkan pengetahuan dan ketrampilan operasional dalam melaksanakan suatu pekerjaan".

Tujuan pendidikan dan pelatihan harus dapat memenuhi kebutuhan yang diinginkan oleh organisasi serta dapat membentuk tingkah laku yang diharapkan serta kondisi-kondisi bagaimana hal tersebut dapat dicapai. Tujuan yang dinyatakan ini kemudian menjadi standar terhadap kinerja individu dan program yang dapat diukur.

Peningkatan pengetahuan dan ketrampilan yang diperoleh melalui keikut sertaan pegawai dalam program pelatihan dan pendidikan diharapkan dapat memberikan semangat dan motivasi baru dalam bekerja. Semangat bekerja yang baik dan dengan dukungan pengetahuan yang baik pula organisasi mengharapkan adanya peningkatan kinerja para pegawai, yang pada akhirnya akan memberikan kontribusi yang positif kepada organisasi.

Selain program pelatihan dan pendidikan, pemberian motivasi terhadap pegawai merupakan salah satu faktor yang memberikan pengaruh terhadap tinggi rendahnya kinerja para pegawai. Motivasi penting bagi suatu organisasi karena mencerminkan upaya organisasi untuk mempertahankan sumber daya manusia, dan wujud perhatian organisasi terhadap pegawai.

\section{cc) (i) (2)}

JURNAL WIDYA This work is licensed under a Creative Commons Attribution-NonCommercialShareAlike 4.0 International License. 
Menurut Robbins dalam (Sayuti, 2006) kepuasan kerja (job satisfaction) adalah keadaan emosional yang positif yang merupakan hasil dari evaluasi pengalaman kerja seseorang. Kepuasan kerja mempunyai korelasi yang sangat kuat kepada tinggi rendahnya motivasi kerja seseorang. Jika seorang karyawan puas terhadap pekerjaannya maka karyawan tersebut akan mempunyai motivasi kerja yang tinggi dan comitted terhadap pekerjaannya.

Seseorang akan merasa dirinya dipercayai dengan diberi tanggung jawab dan wewenang yang lebih besar untuk melakukan kegiatan-kegiatannya. Oleh karena itu, status dan tanggung jawab dapat merupakan stimulus untuk memotivasi diri dalam tugas sehari-hari. Menurut Suyadi (1999) dijelaskan bahwa kinerja adalah hasil yang diperoleh/didapat dicapai seseorang atau kelompok orang dalam suatu organisasi sesuai dengan wewenang dan tanggung jawab masing-masing dalam rangka upaya mencapai tujuan organisasi secara legal, tidak melanggar hukum dan undang-undang. sebagai

Untuk memperjelas teori dan dimensi yang dikemukakan di atas maka dibuat kerangka berpikir

berikut:

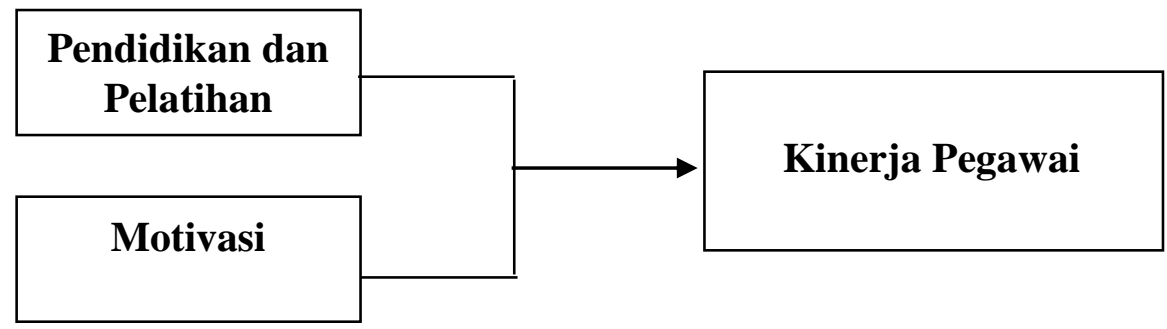

\section{Gambar I.1. Kerangka Berpikir}

\section{I.4. Hipotesis}

Berdasarkan kerangka berpikir di atas, maka hipotesis dari penelitian ini yaitu Diklat Teknis dan motivasi berpengaruh terhadap kinerja alumni Balai Diklat Industri Regional I Medan.

\section{METODOLOGI PENELITIAN}

\section{II.1. Tempat dan Waktu Penelitian}

Penelitian mengenai analisis Pengaruh Diklat Teknis dan motivasi terhadap kinerja alumni Balai Diklat Industri Regional-I Medan dilakukan di Balai Diklat Industri Regional I Medan yang berlokasi di Jalan Medan - Tanjung Morawa. Km. 10/Jln. Damai Nomor 32 Medan. Penelitian dilakukan sejak dari bulan Juli sampai dengan Nopember 2018.

\section{II.2. Metode Penelitian}

Penelitian ini menggunakan pendekatan survey, yaitu metode pengumpulan data primer berdasarkan komunikasi antara peneliti dan responden di mana data peneliti berupa subjek yang menyatakan opini, sikap, pengalaman, karakteristik, subjek penelitian secara individu.

\section{cc) (7)(2)}

JURNAL WIDYA This work is licensed under a Creative Commons Attribution-NonCommercialShareAlike 4.0 International License. 
Singarimbun dan Effendi (1995) menyatakan bahwa "survey merupakan penelitian yang mengambil sampel dari satu populasi dengan menggunakan kuesioner sebagai alat pengumpulan data yang pokok dan secara umum menggunakan metode statistik".

Jenis penelitian ini adalah deskriptif kuantitatif, yaitu penelitian yang bertujuan untuk menguraikan atau menggambarkan tentang sifat-sifat (karakteristik) dari suatu kedaan atau objek penelitian yang dilakukan melalui pengumpulan dan analisis data kuantitatif serta pengujian statistik (Djarwanto, 1996).

Adapun sifat dari penelitian ini adalah penjelasan (explanatory) yang berkaitan dengan kedudukan satu variabel serta hubungannya dengan variabel yang lain (Sugiyono, 2005).

\section{II.3. Populasi dan Sampel}

Populasi dalam penelitian ini berjumlah 179 orang yang berasal dari Dinas Perindustrian yang telah mengikuti Diklat Sistem Industri-I di Balai Diklat Industri Regional - I Medan periode tahun 2015, 2016 dan 2017.

Jumlah sampel diambil dengan menggunakan rumus Slovin, Umar (2004) sebagai berikut:

Di mana: $\quad n=\frac{N}{1+N e^{2}}$

$\mathrm{n} \quad=$ Ukuran sampel

$\mathrm{N} \quad=$ Ukuran populasi

$\mathrm{e} \quad=$ Kesalahan pengambilan sampel

Sebagai peneliti sosial, maka kemungkinan terjadinya kesalahan atau bias dalam penelitian cukup kecil. Tingkat kesalahan yang dapat diterima dalam penelitian ini sebesar 5\% (e=5\%) atau dapat pula dikatakan penelitian menggunakan taraf kepercayaan $95 \%$.

Dengan populasi $(\mathrm{N})$ sebanyak 179 orang dan tingkat kesalahan (e) sebesar 5\%, maka besarnya sampel (n) adalah:

$$
\begin{aligned}
n & =\frac{179}{1+179(0,05)^{2}} \\
& =123,66 \text { orang dibulatkan menjadi } 124 \text { orang }
\end{aligned}
$$

Teknik sampling yang digunakan dalam penelitian ini adalah dengan menggunakan teknik simple random sampling, karena pengambilan sampel dilakukan secara acak tanpa memperhatikan starata yang ada dalam populasi dan anggota populasi dianggap homogen.

\section{II.4. Teknik Pengumpulan Data}

Teknik pengumpulan data dalam penelitian ini dilakukan melalui wawancara, kuesioner, dan studi dokumentasi.

1. Wawancara (interview) dilakukan langsung kepada para pejabat dan staf di Balai Diklat Industri Regional-I Medan, atasan alumni diklat yang memiliki wewenang untuk memberikan data dan informasi yang dibutuhkan dalam penelitian ini. 
2. Daftar pertanyaan (kuesioner) yang diberikan langsung kepada para alumni sebagai responden.

3. Studi dokumentasi, yaitu mengumpulkan beberapa dokumen yang relevan untuk mendukung data penelitian yang diperoleh dari Balai Diklat Industri Regional-I Medan.

\section{II.5. Jenis dan Sumber Data}

Jenis dan sumber data yang dikumpulkan dalam penelitian ini adalah:

1. Data Primer, yaitu data yang diperoleh dari pengamatan (observation), wawancara (interview) dan daftar pertanyaan (questionaire) yang diberikan kepada responden penelitian.

2. Data Sekunder, yaitu data yang diperoleh melalui studi dokumentasi, berupa data jumlah alumni diklat teknis Sistem Industri yang ada di Balai Diklat Industri Regional-I Medan dan data lain yang relevan pada penelitian ini.

\section{II.6. Identifikasi dan Definisi Operasional Variabel}

Variabel bebas (independent variable) untuk hipotesis ini adalah Diklat Teknis $\left(\mathrm{X}_{, 1}\right)$, dan motivasi $\left(\mathrm{X}_{2}\right)$ dan sebagai variabel terikat (dependent variable) adalah kinerja $(\mathrm{Y})$.

Definisi operasional dari masing-masing variabel pada penelitian ini adalah sebagai berikut:

Tabel II.1. Definisi Operasional Variabel

\begin{tabular}{|c|c|c|c|}
\hline Variabel & Definisi & Indikator & Pengkuran \\
\hline $\begin{array}{c}\text { Pendidikan } \\
\text { dan Pelatihan } \\
\text { Teknis } \\
\left(\mathbf{X}_{1}\right)\end{array}$ & $\begin{array}{l}\text { Upaya meningkatkan } \\
\text { ketrampilan dan } \\
\text { pengetahuan pegawai dalam } \\
\text { bidang teknis yang } \\
\text { dibutuhkan untuk } \\
\text { melakukan pekerjaan baik } \\
\text { untuk saat ini atau yang } \\
\text { akan datang. }\end{array}$ & 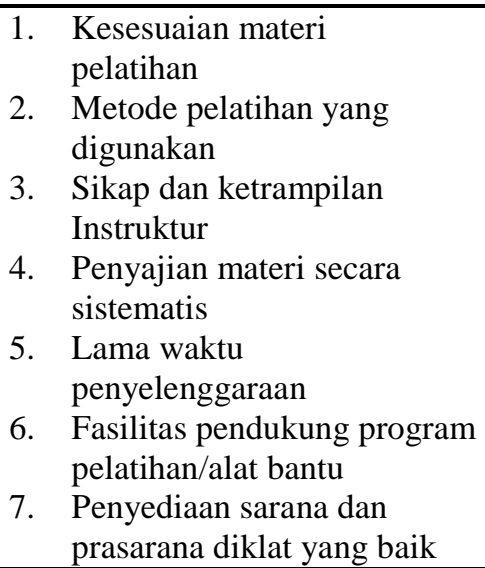 & Skala Likert \\
\hline $\begin{array}{c}\text { Motivasi } \\
\left(\mathbf{X}_{2}\right)\end{array}$ & $\begin{array}{l}\text { Suatu dorongan yang } \\
\text { muncul dari dalam diri } \\
\text { pegawai untuk melakukan } \\
\text { suatu guna mencapai tujuan } \\
\text { dalam rangka memenuhi } \\
\text { keinginannya. }\end{array}$ & $\begin{array}{ll}\text { 1. } & \text { Ketekunan dalam bekerja } \\
\text { 2. Disiplin kerja } \\
\text { 3. Taat pada peraturan } \\
\text { 4. Kesediaan dalam } \\
\text { melaksanakan tugas baru } \\
\text { 5. Menyukai pekerjaan yang } \\
\text { berkaitan dengan prestasi } \\
\text { 6. Selalu berpikir masa depan } \\
\text { 7. Tabah dan tekun dalam } \\
\text { melaksanakan tugas }\end{array}$ & Skala Likert \\
\hline $\begin{array}{l}\text { Kinerja } \\
\text { Pegawai } \\
\text { (Y) }\end{array}$ & $\begin{array}{l}\text { Hasil kerja secara kualitas } \\
\text { dan kuantitas yang dicapai } \\
\text { oleh seseorang pegawai di }\end{array}$ & $\begin{array}{l}\text { 1. Pemahaman dan penguasaan } \\
\text { tugas } \\
\text { 2. Disiplin dalam }\end{array}$ & Skala Likert \\
\hline
\end{tabular}


Volume 1, Nomor 1, April 2020: halaman 8-29

https://jurnal.amikwidyaloka.ac.id/index.php/awl

jurnal@amikwidyaloka.ac.id / editor.jurnalwidya@gmail.com

\begin{tabular}{|c|c|c|c|}
\hline Variabel & Definisi & Indikator & Pengkuran \\
\hline & \begin{tabular}{lrr} 
dalam & \multicolumn{2}{c}{ melaksanakan } \\
tugasnya & sesuai & dengan \\
tanggung jawab & yang \\
diberikan kepadanya. &
\end{tabular} & $\begin{array}{ll}\text { melaksanakan tugas } \\
\text { 3. } \\
\text { Kemampuan dalam } \\
\text { memecahkan masalah } \\
\text { 4. } \begin{array}{l}\text { Kemampuan dalam } \\
\text { menyelesaikan pekerjaan }\end{array} \\
\text { 5. Ketelitian dalam } \\
\text { melaksanakan tugas } \\
\text { 6. Kemampuan bekerja sama } \\
\text { dengan rekan kerja } \\
\text { 7. Ketepatan dalam mengambil } \\
\text { keputusan }\end{array}$ & \\
\hline
\end{tabular}

\section{II.7. Uji Validitas dan Reliabilitas}

\section{II.7.1. Uji Validitas}

Pengujian validitas dalam penelitian ini dengan mengambil sampel 30 (tiga puluh) orang yang tidak termasuk dalam sampel penelitian. Menurut Sugiono (2005) Valid berarti instrumen yang digunakan untuk mendapatkan data dapat digunakan untuk mengukur apa yang seharusnya diukur. Untuk menguji validitas alat ukur, terlebih dahulu dicari harga korelasi antara bagian-bagian dari alat ukur secara keseluruhan dengan cara mengkorelasikan setiap butir alat ukur dengan skor total yang merupakan jumlah tiap skor butir.

Menghitung validitas alat ukur digunakan rumus Pearson Product Moment adalah:

$$
\begin{aligned}
& r_{\text {hitung }}=\frac{n\left(\sum X_{i} Y_{i}\right)-\left(\sum X_{i}\right)\left(\sum Y_{i}\right)}{\sqrt{\left(n \sum X_{i}^{2}-\left(\sum X_{i}\right)^{2}\left(n \sum Y_{i}^{2}-\Sigma Y_{i}\right)^{2}\right)}} \\
& \text { Di mana: } \\
& \mathrm{r}_{\text {hitung }}=\text { koefisien korelasi } \\
& \Sigma X_{\mathrm{i}}=\text { jumlah skor butir } \\
& \Sigma Y_{\mathrm{i}} \quad=\quad \text { jumlah skor total } \\
& \mathrm{n}=\text { jumlah responden }
\end{aligned}
$$

Selanjutnya dihitung dengan uji t dengan rumus:

$$
\text { thitung }=\frac{r \sqrt{n-2}}{\sqrt{1-r^{2}}}
$$

Di mana:

$\mathrm{t}=$ nilai $\mathrm{t}_{\text {hitung }}$

$\mathrm{r}=$ koefisien korelasi

$\mathrm{n}=$ jumlah responden

Distribusi (Tabel t) untuk $\alpha=0,05$ dan derajat kebebasan $(\mathrm{dk}=\mathrm{n}-2)$. Kaedah keputusan: jika $\mathrm{t}_{\text {hitung }}>\mathrm{t}$ tabel berarti valid dan sebaliknya jika $\mathrm{t}_{\text {hitung }}<\mathrm{t}_{\text {tabel }}$ berarti tidak valid.

Jika instrumen itu valid, maka dilihat kriteria penafsiran mengurai indeks korelasinya sebagai berikut:

$$
\text { Antara } \quad 0,8-1,000 \quad \text { Sangat tinggi }
$$

\section{cc) (i) (2) (2)}

JURNAL WIDYA This work is licensed under a Creative Commons Attribution-NonCommercialShareAlike 4.0 International License. 


\section{Jurnal Widya}

Volume 1, Nomor 1, April 2020: halaman 8-29

https://jurnal.amikwidyaloka.ac.id/index.php/awl

jurnal@amikwidyaloka.ac.id / editor.jurnalwidya@gmail.com
Antara $\quad 0,6-0,799$
Tinggi
Antara $\quad 0,4-0,599$
Cukup tinggi
Antara $\quad 0,2-0,399$
Rendah
Antara $0,0-0,199$
Sangat rendah (Tidak Valid)

Menurut Sugiono (2001) minimal mempunyai nilai 0,3 dan lebih dari 0,3 adalah lebih baik.

Tabel II.2. Hasil Uji Validitas Instrumen Variabel Diklat Teknis

\begin{tabular}{lccc}
\hline \multicolumn{1}{c}{ Pertanyaan } & $\begin{array}{c}\text { Corrected Item- } \\
\text { Total Correlation }\end{array}$ & Nilai $\mathbf{r}_{\text {Tabel }}$ & Keterangan \\
\hline Kesesuaian materi pelatihan & 0,841 & 0,3 & Valid \\
\hline Metode pelatihan yang digunakan & 0.736 & 0,3 & Valid \\
\hline Sikap dan ketrampilan Instruktur & 0,617 & 0,3 & Valid \\
\hline Penyajian materi secara sistematis & 0,531 & 0,3 & Valid \\
\hline Lama waktu penyelenggaraan & 0,700 & 0,3 & Valid \\
\hline Fasilitas pendukung diklat/alat bantu & 0,451 & 0,3 & Valid \\
\hline Sarana dan Prasarana Diklat yg baik & 0,683 & 0,3 & Valid \\
\hline
\end{tabular}

Sumber: Data Penelitian 2018 Diolah.

Dari Tabel II.2. di atas dapat dilihat bahwa keseluruhan instrumen variabel Diklat teknis adalah valid. Hal ini dapat dilihat dari nilai Corrected Item-Total Correlation lebih besar dibandingkan dengan 0,3.

Tabel II.3. Hasil Uji Validitas Instrumen Variabel Motivasi

\begin{tabular}{lccc}
\hline \multicolumn{1}{c}{ Pertanyaan } & $\begin{array}{c}\text { Corrected Item- } \\
\text { Total Correlation }\end{array}$ & Nilai $\mathbf{r}_{\text {Tabel }}$ & Keterangan \\
\hline Ketekunan dalam bekerja & 0,697 & 0,3 & Valid \\
\hline Disiplin kerja & 0,696 & 0,3 & Valid \\
\hline Taat pada peraturan & 0,720 & 0,3 & Valid \\
\hline Kesediaan dalam melaksana tugas baru & 0,410 & 0,3 & Valid \\
\hline $\begin{array}{l}\text { Menyukai pekerjaan yg berkaitan dengan } \\
\text { prestasi }\end{array}$ & 0,500 & 0,3 & Valid \\
\hline Selalu berpikir masa depan & 0,479 & 0,3 & Valid \\
\hline Tabah dan tekun dalam tugas & 0,445 & 0,3 & Valid \\
\hline Data Penelitian 2018 Diolah. & & &
\end{tabular}

Sumber: Data Penelitian 2018 Diolah.

Dari Tabel II.3. di atas dapat dilihat bahwa keseluruhan instrumen variabel motivasi adalah valid. Hal ini dapat dilihat dari nilai Corrected Item-Total Correlation lebih besar dibandingkan dengan 0,3.

Tabel II.4. Hasil Uji Validitas Instrumen Variabel Kinerja

JURNAL WIDYA This work is licensed under a Creative Commons Attribution-NonCommercialShareAlike 4.0 International License. 
Volume 1, Nomor 1, April 2020: halaman 8-29

\begin{tabular}{lccc}
\hline \multicolumn{1}{c}{ Pertanyaan } & $\begin{array}{c}\text { Corrected Item- } \\
\text { Total Correlation }\end{array}$ & Nilai $\mathbf{r}_{\text {Tabel }}$ & Keterangan \\
\hline Pemahaman dan Penguasaan tugas & 0,627 & 0,3 & Valid \\
\hline Disiplin dalam melaksanakan tugas & 0,703 & 0,3 & Valid \\
\hline Kemampuan dalam memecahkan masalah & 0,569 & 0,3 & Valid \\
\hline Kemampuan dalam menyelesaikan pekerjaan & 0,747 & 0,3 & Valid \\
\hline Ketelitian dalam melaksanakan tugas & 0,730 & 0,3 & Valid \\
\hline Kemampuan bekerjasama & 0,690 & 0,3 & Valid \\
\hline Ketepatan dalam mengambil keputusan & 0,617 & 0,3 & Valid \\
\hline
\end{tabular}

Sumber: Data Penelitian 2018 Diolah.

Dari Tabel II.4 di atas dapat dilihat bahwa keseluruhan instrumen variabel kinerja adalah valid. Hal ini dapat dilihat dari nilai Corrected Item-Total Correlation lebih besar dibandingkan dengan 0,3.

\section{II.7.2. Uji Reliabilitas}

Uji reliabilitas dilakukan untuk mendapatkan tingkat ketepatan (keterandalan) alat pengumpul data (instrumen) yang digunakan. Uji reliabilitas dilakukan dengan menggunakan rumus Koefisien Alpha $(\alpha)$ dari Cronbach

$$
r_{11}=\left(\frac{k}{k-1}\right)\left(1-\frac{\sum \sigma_{b}^{2}}{\sigma_{i}^{2}}\right)
$$

Di mana:

$$
\begin{array}{ll}
\mathrm{r}_{11} & =\text { realiabilitas instrumen } \\
\mathrm{k} & =\text { banyak butir pertanyaan } \\
\sigma_{i}^{2} & =\text { varian total } \\
\sum \sigma_{b}^{2} & =\text { jumlah varian butir }
\end{array}
$$

Jumlah varian butir dicari terlebih dahulu dengan cara mencari nilai varian tiap butir, kemudian dijumlahkan. Rumus varian yang digunakan adalah sebagai berikut:

$$
\begin{aligned}
\sigma^{2}= & \frac{\sum X \frac{\left(\sum X\right)^{2}}{n}}{n} \\
\text { Di mana: } & =\text { jumlah responden } \\
\mathrm{n} \quad= & \text { nilai skor yang dipilih (total nilai nomor-nomor butir) }
\end{aligned}
$$




\section{Jurnal Widya}

P-ISSN: 2746-5411

Volume 1, Nomor 1, April 2020: halaman 8-29

e-ISSN: $x x x x-x x x x$

https://jurnal.amikwidyaloka.ac.id/index.php/awl

jurnal@amikwidyaloka.ac.id I editor.jurnalwidya@gmail.com

Cronbach alpha yang baik adalah yang makin mendekati 1, menurut Santoso (2002) reliabilitas yang kurang dari 0,6 adalah kurang baik, sedangkan 0,7 dapat diterima dan reliabilitas dengan Cronbach alpha 0,8 atau diatasnya adalah baik.

Tabel II.5. Hasil Uji Reliabilitas

\begin{tabular}{|c|c|c|c|}
\hline Variabel & $\begin{array}{c}\text { Cronbach's } \\
\text { Alpha }\end{array}$ & Nilai $\mathbf{r}_{\text {Tabel }}$ & Keterangan \\
\hline Diklat Teknis & 0,870 & 0,6 & Reliabel \\
\hline Motivasi & 0,880 & 0,6 & Reliabel \\
\hline Kinerja & 0,822 & 0,6 & Reliabel \\
\hline
\end{tabular}

Sumber: Data Penelitian 2018 Diolah.

Dari Tabel II.5 di atas dapat dilihat bahwa keseluruhan variabel adalah reliabel. Hal ini dapat dilihat dari nilai Cronbach's Alpha lebih besar dibandingkan dengan nilai tabelnya sebesar 0,6.

\section{II.8. Model Analisis Data}

Model analisis data yang digunakan pada penelitian ini menggunakan adalah model analisis regresi linier berganda dengan rumus sebagai berikut:

Di mana:

$$
\mathbf{Y}=\mathbf{a}+\mathbf{b}_{1} \mathbf{X}_{1}+\mathbf{b}_{2} \mathbf{X}_{2}+\mathbf{e}
$$

$\mathrm{Y} \quad=$ Kinerja Pegawai

$\mathrm{a} \quad=$ Konstanta

$\mathrm{b}_{1} ; \mathrm{b}_{2} \quad=$ Koefisien regresi variabel independen

$\mathrm{X}_{1} \quad=$ Diklat Teknis

$\mathrm{X}_{2} \quad=$ Motivasi

$\mathrm{e} \quad=$ Variabel yang tidak diteliti

Pengujian hipotesis penelitian secara serempak (simultan) dan parcial dilakukan dengan menggunakan aplikasi software pengolahan data Statistical Package for Social Science (SPSS) versi 15 dengan analisis sebagai berikut:

1. Uji F (Uji secara Simultan)

Uji F dilakukan untuk melihat secara simultan (bersama-sama) apakah ada pengaruh dari variabel bebas (Diklat teknis dan motivasi) terhadap variabel terikat (kinerja).

Model hipotesis yang digunakan dalam uji F ini adalah:

$\mathrm{H}_{0}: \mathrm{b}_{1}, \mathrm{~b}_{2}=0 \quad$ (artinya diklat teknis dan motivasi secara bersama-sama tidak berpengaruh terhadap kinerja alumni)

$\mathrm{H}_{\mathrm{a}} \mathrm{b}_{1, \mathrm{~b}_{2, \neq} 0} \quad$ (artinya diklat teknis dan motivasi secara bersama-sama berpengaruh terhadap Kinerja Alumni)

Nilai $\mathrm{F}_{\text {hitung }}$ akan dibandingkan dengan nilai $\mathrm{F}_{\text {tabel }}$ dengan kriteria pengambilan keputusan yaitu: 


\section{Jurnal Widya}

$\mathrm{H}_{0 \text { : }}$ diterima jika $\mathrm{F}_{\text {hitung }}<\mathrm{F}_{\text {tabel }}$ dengan tingkat kepercayaan (confidence level) $95 \%$ atau $\alpha=0,05$.

$\mathrm{H}_{0}$ : ditolak $\left(\mathrm{H}_{\mathrm{a}}\right.$ diterima) jika $\mathrm{F}_{\text {hitung }}>\mathrm{F}_{\text {tabel }}$ dengan tingkat kepercayaan (confidence interval) $95 \%$ atau $\alpha=$ 0,05 .

Sugiono (2004) menyatakan bahwa: nilai $\mathrm{F}_{\text {hitung }}$ dapat diperoleh dengan menggunakan rumus:

Di mana: $\mathrm{R}=$ koefisien korelasi ganda

$$
F_{\text {hitung }}=\frac{R^{2} / k}{\left(1-R^{2)} /(n-k-1)\right.}
$$

$\mathrm{k}=$ jumlah variabel independen

$$
\mathrm{n}=\text { jumlah anggota sampel }
$$

\section{Uji t (Uji secara Parsial)}

Uji t bertujuan untuk melihat secara parsial apakah ada pengaruh dari Variabel bebas yaitu diklat teknis dan motivasi terhadap variabel terikat yaitu kinerja alumni Balai Diklat Industri Medan.

Model hipotesis yang digunakan dalam uji ini adalah:

$\mathrm{H}_{0:} \mathrm{b}_{1}=0$ (artinya Diklat teknis dan motivasi secara parsial tidak berpengaruh terhadap kinerja alumni Balai Diklat Industri Medan)

$\mathrm{H}_{0:} \mathrm{b}_{1 \neq} 0$ (artinya Diklat teknis dan motivasi secara parsial berpengaruh terhadap kinerja alumni Balai Diklat Industri Medan)

Nilai $t_{\text {hitung }}$ akan dibandingkan dengan nilai $t_{\text {tabel }}$ dengan kriteria pengambilan keputusan yaitu:

$\mathrm{H}_{0 \text { : }}$ diterima jika $\mathrm{t}_{\text {hitung }}<\mathrm{t}_{\text {tabel }}$ pada $\alpha=0,05$.

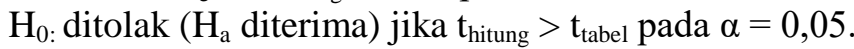

Sugiono (2004) menyatakan bahwa: nilai $t_{\text {hitung }}$ dapat diperoleh dengan menggunakan rumus:

$$
\begin{aligned}
& \text { Di mana: } \mathrm{t}=\text { nilai } \mathrm{t}_{\text {hitung }} \\
& \begin{array}{l}
\mathrm{r}_{p p}=\frac{\underline{\underline{r}}_{p} \sqrt{n-{ }_{k}^{2}}}{1-r_{p}^{2}} \text { relasi parsial yang ditemukan } \\
\mathrm{n}={ }^{2} \text { jumlah sampel }
\end{array}
\end{aligned}
$$

\section{II.9. Uji Asumsi Klasik}

Dalam suatu penelitian, kemungkinan munculnya masalah dalam analisis regresi cukup sering dalam mecocokkan model prediksi kedalam sebuah model yang telah dimasukkan serangkaian data. Masalah ini sering disebut dengan pengujian asumsi klasik yang di dalamnya termasuk pengujian normalitas, multikolinearitas, heteroskedastisitas.

\section{II.9.1. Uji Normalitas}

\section{cc) (i) (2)}

JURNAL WIDYA This work is licensed under a Creative Commons Attribution-NonCommercialShareAlike 4.0 International License. 
Uji ini dilakukan untuk menunjukkan simetris tidaknya distribusi data. Uji normalitas akan dideteksi melalui analisa grafik yang dihasilkan melalui perhitungan regresi dengan SPSS. Dasar pengambilan keputusan menurut Santoso dalam (Santoso, 2002), yaitu:

a. Jika data menyebar sekitar garis diagonal dan mengikuti garis diagonal, maka model regresi memenuhi asumsi normalitas.

b. Jika data menyebar jauh dari garis diagonal atau tidak mengikuti arah garis diagonal maka model tersebut memenuhi asumsi normalitas.

\section{II.9.2. Uji Multikolinieritas}

Uji multikolinieritas bertujuan untuk menguji apakah ada model regresi ditemukan adanya korelasi antar variabel independen. Jika terjadi korelasi, maka terdapat problem multikolinieritas. Pada model regresi yang baik tidak terjadi korelasi di antara variabel independen. Ada beberapa cara yang dapat dilakukan untuk mendeteksi gejala multikolinieritas, yaitu melakukan analisis koefisien korelasi yang tinggi misalnya 0,8 atau $-0,9$, maka dapat diprediksikan akan terjadi multikolinieritas bila $\mathrm{X}_{1}$ dan $\mathrm{X}_{2}$ digunakan secara bersama-sama, melihat toleransi variabel dan variance inflation factor (VIF).

Menurut Santoso (2002), pedoman suatu model regresi yang bebas multikolinier adalah: "Mempunyai VIF kurang dari angka 5 dan mempunyai angka tolerance mendekati 1".

\section{II.9.3. Uji Heteroskedastisitas}

Uji Heteroskedastisitas bertujuan untuk menguji apakah dalam sebuah regresi terjadi ketidak-samaan varians dari residual suatu pengamatan ke pengamatan yang lain. Jika varians dari residual dari satu pengamatan ke pengamatan yang lain tetap, maka disebut homoskedastisitas dan jika varians berbeda disebut heteroskedastisitas. Model regresi yang baik adalah tidak terjadi heteroskedastisitas.

Menurut Santoso (2002), untuk mendeteksi apakah ada atau tidak gejala heteroskedastisitas dapat dilakukan dengan menganalisis penyebaran titik-titik yang terdapat pada Scaterplot yang dihasilkan program SPSS dengan dasar pengambilan keputusan. Jika ada pola tertentu, seperti titik-titik yang ada membentuk suatu pola tertentu yang teratur (bergelombang, melebar, kemudian menyempit) maka terjadi heteroskedastisitas. Jika tidak ada pola yang jelas serta titik-titik menyebar di atas dan di bawah angka 0 pada sumbu Y, maka tidak terjadi heteroskedastisitas.

\section{HASIL PENELITIAN DAN PEMBAHASAN}

\section{III.1. Hasil Penelitian}

\section{III.1.1. Gambaran Umum Balai Diklat Industri Medan}

Balai Latihan Industri Medan adalah salah satu dari 7 (tujuh) Balai Latihan Industri yang ada di Indonesia yang berada di bawah Pusat Pendidikan dan Pelatihan Pegawai berdiri berdasarkan Surat Keputusan Menteri Perindustrian Nomor 674/M/SK/11/1981, tanggal 30 Nopember 1981. Organisasi dan Tata Kerja Balai Latihan Industri Medan adalah unit pelaksana teknis di bidang pendidikan dan pelatihan di lingkungan Departemen Perindustrian di Wilayah Sumatera.

Namun dengan adanya Otonomi daerah serta perkembangan dunia usaha maka Balai Latihan Industri dirubah menjadi Balai Diklat Industri Regional I Medan dibawah Pusat Pendidikan dan Pelatihan Industri berdasarkan Peraturan Menteri Perindustrian Nomor: 50/M-IND/PER/6/2006, tanggal 29 Juni 2006, yang mencakup 4 (empat) daerah kerja yaitu: Provinsi Nanggroe Aceh Darussalam, Provinsi Sumatera Utara, Provinsi Riau dan Provinsi Riau Kepulauan. 
IV.1.1.1. Tugas Pokok dan Fungsi Balai Diklat Industri Regional I Medan

Sesuai dengan Peraturan Menteri Perindustrian Nomor: 50/M-IND/PER/6/2006, tanggal 29 Juni 2006, maka Balai Diklat Industri Mempunyai tugas pokok dan fungsi.

Tugas Pokok

Balai Diklat Industri Mempunyai tugas melaksanakan pendidikan dan pelatihan kepemimpinan, fungsional, teknis dan dunia usaha.

Fungsi

1. Penyusunan rencana dan program pendidikan dan pelatihan kepemimpinan, fungsional, teknis dan dunia usaha.

2. Pelaksanaan pendidikan dan pelatihan kepemimpinan, fungsional, teknis dan dunia usaha.

3. Pelaksanaan pengembangan dan kerjasama pendidikan dan pelatihan.

4. Evaluasi/monitoring dan pelaporan kegiatan pendidikan dan pelatihan.

5. Pelaksanaan urusan tata usaha Balai Diklat Industri.

III.1.1.2. Visi dan Misi Balai Diklat Industri Regional I Medan

Balai Diklat Industri Regional I Medan di dalam melaksanakan tugas pokok dan fungsinya sebagai aparatur pemerintahan di dalam membina dan mengembangkan aparatur Departemen Perindustrian dan Dunia Usaha mempunyai visi sebagai berikut: "Menjadi institusi terdepan dalam pengembangan aparatur industri dan dunia usaha dalam bidang teknologi industri dan manajemen bisnis terapan".

Balai Diklat Industri Regional I Medan mempunyai misi untuk mendukung agar visi tersebut dapat diwujudkan sebagai berikut:

1. Meningkatkan mutu dan kemampuan serta ketrampilan Sumber Daya Manusia dalam bidang substansi industri dan manajerial.

2. Menyediakan program pembelajaran sesuai kebutuhan.

3. Membudayakan organisasi belajar yang secara terus-menerus.

III.1.1.3. Struktur Organisasi Balai Diklat Industri Regional I Medan

Suatu perusahaan baik instansi pemerintah maupun swasta membutuhkan adanya struktur organisasi untuk dapat bekerja secara efektif. Struktur organisasi adalah pola formal aktivitas dan hubungan antara berbagai sub-unit organisasi yang secara jelas dapat terlihat konfigurasi posisi, penjabaran tugas, dan garis wewenang diantara bagian suatu organisasi. Balai Diklat Industri Regional I Medan didukung oleh 22 (dua puluh dua) orang pegawai yang mempunyai tugas dan tanggung jawab yang jelas.

Tugas dan fungsi dari setiap bagian dalam struktur organisasi pada Balai Diklat Industri Regional I Medan adalah sebagai berikut:

1. Kepala Balai di dalam melaksanakan tugasnya dibantu oleh 3 (tiga) orang pegawai eselon IV.

2. Kasubag Tata Usaha, yang membawahi tugas-tugas: Kepegawaian, Keuangan, Umum dan Perlengkapan.

3. Kepala Seksi Program dan Kerjasama, yang membawahi tugas-tugas: Program Diklat, Kurikulum dan Silabus Diklat, Pelaksanaan Diklat dan Melakukan kerjasama dengan pihak lain.

4 Kepala Seksi Evaluasi dan Pelaporan yang membawahi tugas-tugas: Evaluasi diklat, monitoring dan pelaporan. berikut.

Struktur organisasi Balai Diklat Industri Regional I Medan dapat dilihat pada Gambar III.1 sebagai

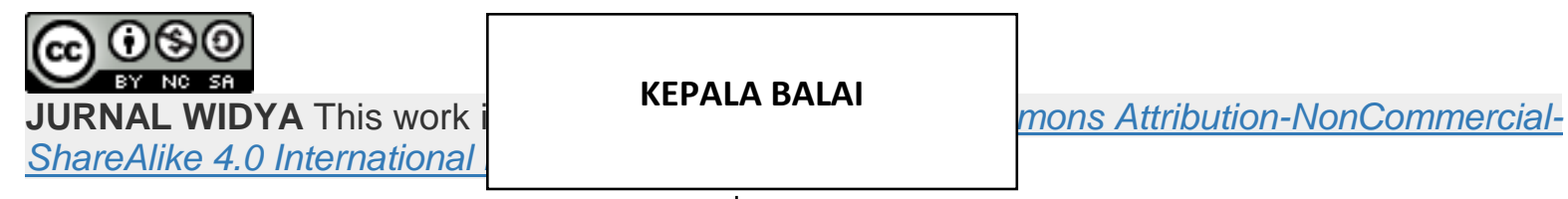


Volume 1, Nomor 1, April 2020: halaman 8-29

Gambar III.1. Struktur Organisasi Balai Diklat Regional-I Medan Peraturan Menteri Perindustrian Nomor : 50/M-IND/PER/6/2006 Tanggal 29 Juni 2006

Adapun uraian tugas dari struktur organisasi tersebut adalah sebagai berikut:

1. Kepala Balai Diklat Industri

a. Ikhtisar Jabatan

Merencanakan, mengkoordinasi, memantau kegiatan diklat dan tugas rutin bidang ketatausahaan yang di Balai Diklat Industri Medan, agar pelaksanaannya sesuai dengan program yang telah ditetapkan memimpin pelaksanaan tugas pendidikan dan pelatihan industri.

b. Rincian Tugas

1. Menyusun rencana operasional terhadap kegiatan yang akan dilakukan sesuai dengan pendelegasian wewenang yang diberikan oleh Pusdiklat Industri.

2. Membuat rencana operasional diklat di bidang Industri.

3. Membagi tugas kepada bawahan sesuai dengan tanggung jawab dan wewenang masing-masing.

4. Membagi tugas kepada bawahan sesuai tugasnya kepada Sub Bagian dan Kas dengan baik demi kelancaran pelaksanaan tugas. 
5. Memberi petunjuk kepada bawahan cara-cara menyelesaikan tugas sesuai dengan kegiatan yang ada di Balai Industri (BDI).

6. Mengkoordinasi kegiatan diklat dan ketatausahaan yang ada pada masing-masing seksi dan Sub Bagian di Diklat Industri.

7. Mempelajari dan merencanakan pelaksanaan diklat dengan membicara-kan melalui rapat bersama Pejabat dan inti Balai Diklat Industri.

8. Menindak lanjuti surat-surat dari Pusdiklat Industri melalui rapat dengan para pelaksana.

9. Mencari peluang dan menjalin kerjasama dengan unit-unit terkait baik di dalam maupun di luar organisasi untuk meningkatkan kinerja organisasinya.

10. Menyelia penyelenggara diklat untuk mengetahui sejauhmana realisasi pelaksanaan sesuai dengan rencana yang ditentukan.

11. Memantau pelaksanaan diklat melalui rapat-rapat atau koordinasi untuk mengetahui permasalahan dan perkembangan.

12. Memberikan disposisi terhadap surat masuk untuk selanjutnya diteruskan kepada bawahan untuk segera dilaksanakan.

13. Menandatangani surat-surat keluar yang diajukan bawahan sesuai dengan tugas dan bidangnya.

14. Mengevaluasi pelaksanaan diklat di bidang industri.

15. Membuat laporan diklat di bidang industri.

16. Melakukan pengawasan melekat kepada para bawahan.

2. Kepala Sub Bagian Tata Usaha

a. Ikhtisar jabatan:

Merencanakan, mengkoordinasikan, memantau dan membuat laporan kegiatan rutin di bidang kepegawaian, keuangan, inventaris dan perlengkapan, surat menyurat dan kerumahtanggaan Balai Diklat Industri Medan sesuai dengan ketentuan yang berlaku.

b. Rincian Tugas:

1. Membuat rencana kegiatan Sub Bagian Tata Usaha.

2. Memberikan petunjuk kepada bawahan tentang cara-cara menyelesaikan tugas pada Bagian Tata Usaha.

3. Mengkoordinasikan kegiatan di bidang yang ada di bawahnya.

4. Menyusun prosedur ketatalaksanaan untuk kelancaran pelaksanaan tugas.

5. Menyusun rencana kebutuhan inventaris, perlengkapan rumah tangga Balai Diklat Industri Medan.

6. Meneliti dan menyelia kebutuhan pemeliharaan.

7. Mengkoordinasikan pengadaan inventaris dan perlengkapan Balai Diklat Industri Medan sesuai dengan rencana dan kebutuhan.

8. Mengkoordinasikan kegiatan yang menyangkut masalah kebersihan, ketertiban dan keamanan Balai Diklat Industri Medan.

9. Mengatur penatausahaan kepegawaian meliputi promosi, mutasi dan kesejateraan pegawai.

10. Menyelia dan mengatur penggunaan asrama/inventaris.

11. Memberikan masukan kepada Kepala Balai Diklat Industri di bidang ketatausahaan sebagai bahan masukan pimpinan pengambilan keputusan.

12. Membuat laporan tentang kegiatan Sub Bagian Tata Usaha.

13. Membagi tugas kepada bawahan sesuai dengan tugasnya pada bidang masing-masing.

14. Membimbing bawahan dalam pelaksanaan tugas agar diperoleh hasil kerja yang berdaya guna. 
15. Memeriksa konsep surat ketatausahaan dan kerumahtanggaan.

16. Membuat rencana kebutuhan ATK, pegawai dan keuangan.

17. Memeriksa hasil kerja bawahan.

18. Membuat laporan pelaksanaan tugas tata usaha.

19. Melaksanakan tugas lain sesuai dengan petunjuk atasan.

3. Kepala Seksi Program dan Kerjasama Antar Diklat

a. Ikthisar Jabatan:

Memimpin pelaksanaan tugas penyiapan diklat, pengurusan tenaga pengajar, ruang kuliah, absensi peserta pelaksanaan diklat serta memberikan informasi ke instansi lain dalam rangka kerjasama diklat.

b. Uraian Tugas:

1. Membuat rencana kegiatan penyiapan program diklat.

2. Membagi habis tugas kepada bawahan sesuai dengan tugas masing-masing.

3. Kepala Seksi Program dan Kerjasama Antar Diklat membawahi: penyusunan program diklat, pengadministrasian diklat, perpustakaan, dokumentasi dan informasi.

4. Membuat konsep surat menyurat yang berkaitan dengan penyelenggara diklat.

5. Mengatur penyelenggara diklat, diskusi, seminar, out bond dan PKL.

6. Menyusun jadwal kegiatan diklat selama satu tahun anggaran.

7. Merekrut, menyiapkan peserta dan menghubungi tenaga pengajar.

8. Menyusun kurikulum dan silabi diklat.

9. Mengatur pembagian materi dan perlengkapan peserta diklat.

10. Melakukan pengembangan kurikulum dan silabi yang pernah diselenggarakan dan mengembangkan diklat baru.

11. Mengawasi pelaksanaan diklat.

12. Memeriksa sertifikat diklat.

13. Mencari memberi data dan informasi diklat ke instansi terkait dalam rangka kerjasama diklat.

14. Memeriksa penyusunan ranking.

15. Melaksanakan tugas lain sesuai petunjuk atasan.

4. Kepala Seksi Evaluasi dan Pelaporan

a. Ikhtisar Jabatan:

Memimpin tugas pelaksanaan, evaluasi dan pembuatan laporan pelaksanaan diklat, laporan tahunan, merencanakan monitoring pasca diklat.

b. Rincian Tugas:

1. Membuat rencana/outline dan pembuatan laporan pelaksanaan kegiatan diklat serta laporan tahunan.

2. Membagi tugas kepada bawahan sesuai dengan tugas masing-masing.

3. Kepala seksi evaluasi dan pelaporan membawahi: penyusunan laporan, evaluasi dan monitoring pasca diklat.

4. Memantau pelaksanaan kegiatan diklat.

5. Membuat konsep daftar pertanyaan, lokasi, petugas serta anggaran yang digunakan dalam rangka monitoring pasca diklat dan training needs.

6. Membuat training design sesuai hasil monitoring pasca diklat dan training needs.

7. Mencatat dan menyimpan dokumen sebagai bahan informasi.

8. Melaksanakan tugas sesuai petunjuk. 


\section{III.1.2. Karakteristik Responden}

Responden penelitian ini adalah sebanyak 124 orang yang merupakan pegawai yang berasal dari Dinas Perindustrian yang telah mengikuti Diklat Sistem Industri I di Balai Diklat Industri Regional - I Medan. III.1.2.1. Karakteristik Responden Berdasarkan Jenis Kelamin

Karakteristik responden berdasarkan jenis kelamin dapat dilihat pada tabel di bawah ini.

Tabel III. 1. Jenis Kelamin Responden

\begin{tabular}{clcc}
\hline \hline No. & Jenis Kelamin & Jumlah & Persentase \\
\hline \hline 1 & Laki-Laki & 72 orang & 58 \\
\hline \hline 2 & Perempuan & 52 orang & 42 \\
\hline \hline Jumlah & & 124 orang & 100 \\
\hline \hline
\end{tabular}

Sumber: Data Penelitian 2018 Diolah.

Dari tabel di atas dapat dilihat bahwa jumlah laki-laki jauh lebih banyak dibandingkan perempuan. Jumlah laki-laki ada sebanyak 72 orang (58\%) dan perempuan sebanyak 52 orang (42\%). Ini menandakan bahwa peserta yang telah mengikuti Diklat Sistem Industri I di Balai Diklat Industri Regional - I Medan lebih banyak laki-laki dibandingkan dengan perempuan.

III.1.2.2. Karakteristik Responden Berdasarkan Tingkat Pendidikan

Karakteristik responden berdasarkan tingkat pendidikan dapat dilihat pada tabel di bawah ini.

Tabel III.2. Tingkat Pendidikan Responden

\begin{tabular}{clcc}
\hline \hline No. & Tingkat Pendidikan & Jumlah & Persentase \\
\hline \hline 1 & SMU & 40 orang & 32,3 \\
\hline \hline 2 & D1/D2 & 1 orang & 0,8 \\
\hline \hline 3 & D3 & 37orang & 29,9 \\
\hline \hline 4 & S1 & 44 orang & 35,4 \\
\hline \hline 5 & S2 & 2 orang & 1,6 \\
\hline \hline Jumlah & & 124 orang & 100 \\
\hline \hline
\end{tabular}

Sumber: Data Penelitian 2018 Diolah.

Dari tabel di atas dapat dilihat bahwa tingkat pendidikan peserta yang telah mengikuti Diklat Sistem Industri I di Balai Diklat Industri Regional - I Medan adalah beragam. Jumlah yang memiliki jenjang pendidikan SMU adalah sebanyak 40 orang (32,3\%), D1/D2 sebanyak 1 orang $(0,8 \%)$, D3 sebanyak 37 orang $(29,9 \%)$, S1 sebanyak 44 orang $(35,4 \%)$ dan S2 adalah sebanyak 2 orang $(1,6 \%)$. Hal ini mengindikasikan bahwa diklat tersebut tidak menetapkan persyaratan kebutuhan akan peserta dengan tingkat pendidikan S1. Hal yang penting bagi diklat tersebut adalah peserta telah menjadi PNS di Dinas Perindustrian.

\section{c) (7)(2)}

JURNAL WIDYA This work is licensed under a Creative Commons Attribution-NonCommercialShareAlike 4.0 International License. 
III.1.2.3. Karakteristik Responden Berdasarkan Lama Bekerja

Karakteristik responden berdasarkan lama bekerja dapat dilihat pada tabel di bawah ini.

Tabel III. 3. Lama Bekerja Responden

\begin{tabular}{clll}
\hline \hline No. & \multicolumn{1}{c}{ Lama Bekerja } & Jumlah & $\%$ \\
\hline \hline 1 & $0-5$ Tahun & 17 orang & 14 \\
\hline \hline 2 & $6-10$ Tahun & 41 orang & 33 \\
\hline \hline 3 & $11-15$ Tahun & 35 orang & 28 \\
\hline \hline 5 & $16-20$ Tahun & 17 orang & 14 \\
\hline \hline Jumlah & 14 orang & 11 \\
\hline \hline
\end{tabular}

Sumber: Data Penelitian 2018 Diolah.

Dari tabel di atas dapat dilihat bahwa jumlah peserta diklat yang memiliki pengalaman kerja $6-10$ tahun adalah yang paling banyak. Jumlah peserta diklat yang memiliki pengalaman kerja $0-5$ tahun adalah sebanyak 17 orang (14\%), memiliki pengalaman kerja selama 6 - 10 tahun adalah sebanyak 41 orang (33\%), yang memiliki pengalaman kerja 11 - 15 tahun adalah sebanyak 35 orang (28\%), yang memiliki pengalaman kerja 16 - 20 tahun adalah sebanyak 17 orang (14\%), dan yang memiliki pengalaman kerja $>20$ tahun adalah sebanyak 14 orang $(11 \%)$.

Sebaran pengalaman kerja di atas mengindikasikan bahwa kebanyakan para peserta diklat belum memiliki pengalaman kerja yang sudah cukup lama. Hanya beberapa diantaranya yang memiliki pengalaman kerja yang cukup lama sehingga mendukung kinerja peserta diklat di kelas yang sangat membutuhkan pengalaman sebagai salah satu faktor yang mempengaruhi kinerja peserta diklat.

\section{III.1.3. Analisis Deskriptif Variabel}

Penelitian ini mengamati 1 (satu) variabel terikat yaitu kinerja peserta diklat (Y) dan mengamati variabel bebas yaitu Diklat teknis $\left(\mathrm{X}_{1}\right)$ dan motivasi $\left(\mathrm{X}_{2}\right)$. Masing-masing variabel, indikatornya dituangkan ke dalam pertanyaan-pertanyaan yang dibuat dalam skala likert untuk memasukkan kategori dari jawaban responden terhadap pertanyaan yang diajukan.

\section{III.1.3.1. Penjelasan Responden atas Variabel Kinerja}

Penjelasan responden untuk pertanyaan pemahaman dan penguasaan tugas akan menghasilkan kinerja yang baik maka 5\% menyatakan kurang setuju, $14 \%$ menyatakan setuju, $47 \%$ menyatakan sangat setuju dan 35\% menyatakan sangat setuju sekali. Dengan jawaban ini maka dapat dikatakan bahwa peserta diklat telah memandang penting untuk pemahaman dan penguasaan tugas akan menghasilkan kinerja yang baik.

Penjelasan responden untuk pertanyaan disiplin dalam melakukan pekerjaan akan menghasilkan kinerja yang baik, maka 2\% menyatakan kurang setuju, 19\% menyatakan setuju, 52\% menyatakan sangat setuju dan $27 \%$ menyatakan sangat setuju sekali. Dengan jawaban ini maka dapat dikatakan bahwa peserta diklat telah melaksanakan disiplin dalam melakukan pekerjaan akan menghasilkan kinerja yang baik.

Penjelasan responden untuk pertanyaan diklat teknis dalam menemukan dan memecahkan permasalahan sangat dibutuhkan dalam menghasilkan pekerjaan yang baik, maka $2 \%$ menyatakan kurang setuju, 25\% menyatakan setuju, 43\% menyatakan sangat setuju dan 30\% menyatakan sangat setuju sekali. 
Dengan jawaban ini maka dapat dikatakan bahwa kemampuan dalam menemukan dan memecahkan permasalahan sangat dibutuhkan dalam menghasilkan pekerjaan yang baik.

Penjelasan responden untuk pertanyaan kemampuan dalam menyelesaikan pekerjaan merupakan hal yang utama dalam melakukan pekerjaan, maka $1 \%$ menyatakan tidak setuju, $2 \%$ menyatakan kurang setuju, $27 \%$ menyatakan setuju, $40 \%$ menyatakan sangat setuju dan $30 \%$ menyatakan sangat setuju sekali. Dengan jawaban ini maka dapat dikatakan bahwa kemampuan dalam menyelesaikan pekerjaan merupakan hal yang utama dalam melakukan pekerjaan.

Penjelasan responden untuk pertanyaan ketelitian dalam melaksanakan tugas juga merupakan faktor yang utama dalam menghasilkan pekerjaan yang baik maka $1 \%$ menyatakan tidak setuju, $2 \%$ menyatakan kurang setuju, 25\% menyatakan setuju, $44 \%$ menyatakan sangat setuju dan $28 \%$ menyatakan sangat setuju sekali. Dengan jawaban ini maka dapat dikatakan bahwa ketelitian dalam melaksanakan tugas juga merupakan faktor yang utama dalam menghasilkan pekerjaan yang baik.

Penjelasan responden untuk pertanyaan kerjasama dalam suatu tim merupakan salah satu faktor yang dipertimbangkan dalam menghasilkan kinerja yang baik maka $1 \%$ menyatakan tidak setuju, $2 \%$ menyatakan kurang setuju, 29\% menyatakan setuju, $43 \%$ menyatakan sangat setuju dan $26 \%$ menyatakan sangat setuju sekali. Dengan jawaban ini maka dapat dikatakan bahwa kerjasama dalam suatu tim merupakan salah satu faktor yang dipertimbangkan dalam menghasilkan kinerja yang baik.

Penjelasan responden untuk pertanyaan ketepatan dalam pengambilan keputusan merupakan salah satu faktor dalam menunjang hasil yang baik maka $1 \%$ menyatakan tidak setuju, $4 \%$ menyatakan kurang setuju, 25\% menyatakan setuju, $47 \%$ menyatakan sangat setuju dan 23\% menyatakan sangat setuju sekali. Dengan jawaban ini maka dapat dikatakan bahwa peserta ketepatan dalam pengambilan keputusan merupakan salah satu faktor dalam menunjang hasil yang baik.

Hasil sepenuhnya jawaban responden tersebut dapat dilihat pada tabel di bawah ini.

Tabel III.4. Penjelasan Responden atas Pertanyaan Variabel Kinerja

\begin{tabular}{|c|c|c|c|c|c|c|}
\hline \multirow[t]{2}{*}{ No } & \multirow[t]{2}{*}{ Pertanyaan } & \multicolumn{5}{|c|}{ Jawaban } \\
\hline & & SSS & SS & $\mathbf{S}$ & KS & TS \\
\hline 1 & $\begin{array}{l}\text { Pemahaman dan penguasaan tugas akan } \\
\text { menghasilkan kinerja yang baik }\end{array}$ & 35 & 47 & 14 & 5 & 0 \\
\hline 2 & $\begin{array}{l}\text { Disiplin dalam melakukan pekerjaan akan } \\
\text { menghasilkan kinerja yang baik }\end{array}$ & 27 & 52 & 19 & 2 & 0 \\
\hline 3 & $\begin{array}{l}\text { Kemampuan dalam menemukan dan } \\
\text { memecahkan permasalahan sangat dibutuhkan } \\
\text { dalam menghasilkan pekerjaan }\end{array}$ & 30 & 43 & 25 & 2 & 0 \\
\hline 4 & $\begin{array}{l}\text { Kemampuan dalam menyelesaikan pekerjaan } \\
\text { merupakan hal yang utama dalam melakukan } \\
\text { pekerjaan }\end{array}$ & 30 & 40 & 27 & 2 & 1 \\
\hline 5 & $\begin{array}{l}\text { Ketelitian dalam melaksanakan tugas juga } \\
\text { merupakan faktor yang utama dalam } \\
\text { menghasilkan pekerjaan yang baik }\end{array}$ & 28 & 44 & 25 & 2 & 1 \\
\hline 6 & $\begin{array}{l}\text { Kerjasama dalam suatu tim merupakan salah } \\
\text { satu faktor yang dipertimbangkan dalam } \\
\text { menghasilkan kinerja yang baik }\end{array}$ & 26 & 43 & 29 & 2 & 1 \\
\hline 7 & $\begin{array}{l}\text { Ketepatan dalam pengambilan keputusan } \\
\text { merupakan salah satu faktor dalam menunjang }\end{array}$ & 23 & 47 & 25 & 4 & 1 \\
\hline
\end{tabular}

\section{cc) (i) (2) (-)}

JURNAL WIDYA This work is licensed under a Creative Commons Attribution-NonCommercialShareAlike 4.0 International License. 
hasil yang baik

Sumber: Data Penelitian 2018 Diolah.

\section{III.1.3.2. Penjelasan Responden atas Variabel Diklat Teknis}

Penjelasan responden untuk pertanyaan kesesuaian materi, Peserta diklat menyatakan kesesuaian materi diklat sangat dibutukan, maka 2\% menyatakan kurang setuju, 17\% menyatakan setuju, $35 \%$ menyatakan sangat setuju dan 46\% menyatakan sangat setuju sekali. Dengan jawaban ini maka dapat dikatakan bahwa kesesuaian materi diklat dalam dalam diklat teknis harus sesuai..

Penjelasan responden untuk pertanyaan dalam mengerjakan metode pelatihan yang digunakan, peserta merasakan sangat perlu metode yang baik dalam penyelenggaraan diklat agar dapat dengan cepat memahami, maka 2\% menyatakan kurang setuju, 18\% menyatakan setuju, 48\% menyatakan sangat setuju dan 32\% menyatakan sangat setuju sekali. Dengan jawaban ini maka dapat dikatakan bahwa dalam pelaksanaan diklat teknis sangat diperlukan metode yang baik yang dapat diterima peserta diklat yang telah dewasa.

Penjelasan responden untuk pertanyaan sikap dan ketrampilan instruktur, Peserta diklat menyatakan ketrampilan instruktur sangat dibutuhkan, maka $2 \%$ menyatakan tidak setuju, $2 \%$ menyatakan kurang setuju, $27 \%$ menyatakan setuju, 37\% menyatakan sangat setuju dan 33\% menyatakan sangat setuju sekali. Dengan jawaban ini maka dapat dikatakan bahwa penyelenggara diklat harus benar-benar mencari instruktur yang menguasai bidangnya.

Penjelasan responden untuk pertanyaan penyajian materi secara sistematis, Peserta diklat mengharapkan penyajian materi secara sistematis, maka $2 \%$ menyatakan kurang setuju, $23 \%$ menyatakan setuju, 40\% menyatakan sangat setuju dan 35\% menyatakan sangat setuju sekali. Dengan jawaban ini maka dapat dikatakan penyajian yang sistematis sangat diharapkan para peserta diklat.

Penjelasan responden untuk pertanyaan lamanya waktu penyelenggaraan, Peserta diklat menyatakan waktu yang dibutuhkan harus mencukupi, maka $2 \%$ menyatakan tidak setuju, $1 \%$ menyatakan kurang setuju, $25 \%$ menyatakan setuju, 46\% menyatakan sangat setuju dan $27 \%$ menyatakan sangat setuju sekali. Dengan jawaban ini maka dapat dikatakan bahwa lamanya waktu penyelenggaraan sangat mempengaruhi para peserta.

Penjelasan responden untuk pertanyaan fasilitas pendukung/alat bantu, Peserta diklat membutuhkan alat bantu, maka 2\% menyatakan kurang setuju, 27\% menyatakan setuju, $43 \%$ menyatakan sangat setuju dan $28 \%$ menyatakan sangat setuju sekali. Dengan jawaban ini maka dapat dikatakan bahwa dalam penyelengaraan diklat fasilitas pendukung atau alat bantu sangat dibutuhkan.

Penjelasan responden untuk pertanyaan sarana dan prasarana, Peserta diklat membutuhkan sarana dan prasarana, maka 1\% menyatakan tidak setuju, 2\% menyatakan kurang setuju, 24\% menyatakan setuju, $45 \%$ menyatakan sangat setuju dan 28\% menyatakan sangat setuju sekali. Dengan jawaban ini maka dapat dikatakan bahwa dalam pelaksanaan diklat sarana dan prasarana yang baik sangat dibutuhkan untuk mendukung kegiatan diklat.

Tabel III.5. Penjelasan Responden atas Pertanyaan Variabel Diklat Teknis

\begin{tabular}{clccccc}
\hline \multirow{2}{*}{ No } & \multirow{2}{*}{ Pertanyaan } & \multicolumn{4}{c}{ Jawaban } \\
\cline { 3 - 6 } & & SSS & SS & S & KS & TS \\
\hline 1 & Kesesuaian materi diklat & 46 & 35 & 17 & 2 & 0 \\
\hline 2 & Metode Pelatihan yang digunakan & 32 & 48 & 18 & 2 & 0 \\
\hline 3 & Sikap dan ketrampilan instruktur & 33 & 37 & 27 & 2 & 2 \\
\hline
\end{tabular}




\begin{tabular}{lllllll}
\hline 4 & Penyajian materi secara sistematis & 35 & 40 & 23 & 2 & 0 \\
\hline 5 & Lamanya waktu penyelenggaraan & 27 & 46 & 25 & 1 & 2 \\
\hline 6 & Fasilitas Pendukung/alat bantu & 28 & 43 & 27 & 2 & 0 \\
\hline 7 & Sarana dan prasarana diklat & 28 & 45 & 24 & 2 & 1 \\
\hline
\end{tabular}

Sumber: Data Penelitian 2018 Diolah.

\section{III.1.3.3. Penjelasan Responden atas Variabel Motivasi}

Penjelasan responden untuk pertanyaan ketekunan dalam melaksanakan pekerjaan merupakan salah satu hal yang dipertimbangkan dalam menghasilkan pekerjaan yang baik, maka 3\% menyatakan kurang setuju, 17\% menyatakan setuju, 39\% menyatakan sangat setuju dan 41\% menyatakan sangat setuju sekali. Dengan jawaban ini maka dapat dikatakan bahwa ketekunan dalam melaksanakan pekerjaan merupakan salah satu hal yang dipertimbangkan dalam menghasilkan pekerjaan yang baik.

Penjelasan responden untuk pertanyaan disiplin kerja merupakan salah satu faktor yang dipertimbangkan dalam bekerja, maka $1 \%$ menyatakan tidak setuju, 2\% menyatakan kurang setuju, $18 \%$ menyatakan setuju, 50\% menyatakan sangat setuju dan 30\% menyatakan sangat setuju sekali. Dengan jawaban ini maka dapat dikatakan bahwa disiplin kerja merupakan salah satu faktor yang dipertimbangkan dalam bekerja.

Penjelasan responden untuk pertanyaan dalam melakukan pekerjaan, ketaatan dalm peraturtan merupakan hal yang harus dipertimbangkan, saya merasa aman dalam bekerja, maka $2 \%$ menyatakan tidak setuju, $1 \%$ menyatakan kurang setuju, 21\% menyatakan setuju, $49 \%$ menyatakan sangat setuju dan $27 \%$ menyatakan sangat setuju sekali. Dengan jawaban ini maka dapat dikatakan bahwa dalam melakukan pekerjaan, ketaatan dalam peraturtan merupakan hal yang harus dipertimbangkan.

Penjelasan responden untuk pertanyaan dalam bekerja, peserta selalu bersedia dalam melaksanakan tugas-tugas yang baru, maka 2\% menyatakan kurang setuju, 32\% menyatakan setuju, 37\% menyatakan sangat setuju dan 28\% menyatakan sangat setuju sekali. Dengan jawaban ini maka dapat dikatakan bahwa dalam bekerja, peserta selalu bersedia dalam melaksanakan tugas-tugas yang baru.

Penjelasan responden untuk pertanyaan prestasi kerja merupakan tujuan dalam melaksanakan pekerjaan, maka $1 \%$ menyatakan tidak setuju, 2\% menyatakan kurang setuju, 32\% menyatakan setuju, 36\% menyatakan sangat setuju dan $28 \%$ menyatakan sangat setuju sekali. Dengan jawaban ini maka dapat dikatakan bahwa prestasi kerja merupakan tujuan dalam melaksanakan pekerjaan.

Penjelasan responden untuk pertanyaan dalam bekerja, peserta selalu berpikir untuk masa depan, maka 2\% menyatakan kurang setuju, 38\% menyatakan setuju, 31\% menyatakan sangat setuju dan 29\% menyatakan sangat setuju sekali. Dengan jawaban ini maka dapat dikatakan bahwa dalam bekerja, peserta selalu berpikir untuk masa depan.

Penjelasan responden untuk pertanyaan ketekunan dan ketabahan merupakan salah satu faktor yang dipertimbangkan dalam melakukan pekerjaan, maka $1 \%$ menyatakan tidak setuju, $3 \%$ menyatakan kurang setuju, 33\% menyatakan setuju, 35\% menyatakan sangat setuju dan 27\% menyatakan sangat setuju sekali. Dengan jawaban ini maka dapat dikatakan bahwa ketekunan dan ketabahan merupakan salah satu faktor yang dipertimbangkan

dalam melakukan pekerjaan.

Tabel III.6. Penjelasan Responden atas Pertanyaan Variabel Motivasi

\begin{tabular}{lll}
\hline No & Pertanyaan & Jawaban \\
\hline
\end{tabular}


Volume 1, Nomor 1, April 2020: halaman 8-29

https://jurnal.amikwidyaloka.ac.id/index.php/awl

jurnal@amikwidyaloka.ac.id / editor.jurnalwidya@gmail.com

\begin{tabular}{llccccc}
\hline & & SSS & SS & S & KS & TS \\
\hline 1 & Ketekunan dalam melaksanakan pekerjaan & 41 & 39 & 17 & 3 & 0 \\
\hline 2 & Disiplin kerja merupakan faktor dalam bekerja & 30 & 50 & 18 & 2 & 1 \\
\hline 3 & Ketaatan dalam peraturan & 27 & 49 & 21 & 1 & 2 \\
\hline 4 & Bersedia melaksanakan tugas yang baru & 28 & 37 & 32 & 2 & 0 \\
\hline 5 & Prestasi merupakan tujuan & 28 & 36 & 32 & 2 & 1 \\
\hline 6 & Selalu berpikir untuk masa depan & 29 & 31 & 38 & 2 & 0 \\
\hline 7 & Tabah dalam bekerja & 27 & 35 & 33 & 3 & 1 \\
\hline
\end{tabular}

Sumber: Data Penelitian 2018 Diolah.

\section{III.1.4. Pengujian Asumsi Klasik}

Pengujian asumsi klasik dilakukan terlebih dahulu agar dapat mendeteksi apakah terpenuhi atau tidak terpenuhinya asumsi-asumsi klasik dalam suatu model regresi berganda. Pengujian ini dilakukan agar lebih relevan dalam melakukan interpretasi dan analisis nantinya.

III.1.4.1. Uji Normalitas

Uji untuk mengetahui apakah data berdistribusi normal atau mendekati normal dilakukan dengan Regression Standarized Residual. Hasil pengujian dapat dilihat pada gambar di bawah ini:

\section{Normal P.P Plot of Regression Standardized Residua}

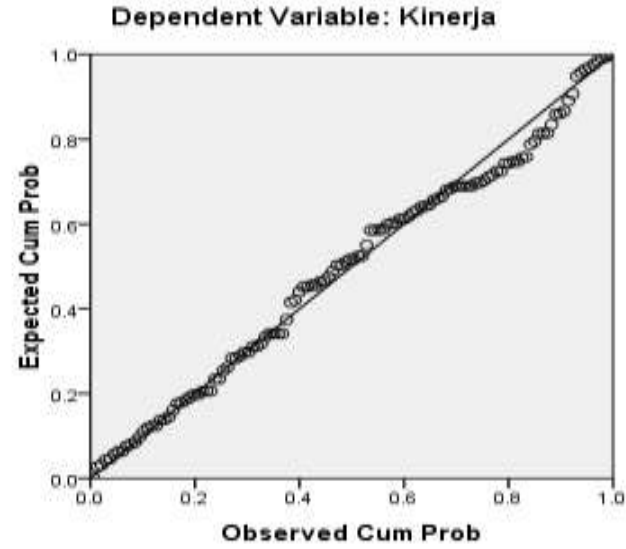

Sumber: Data Penelitian 2018 Diolah

\section{Gambar III.2. Hasil Pengujian Secara Grafik Normalitas Data}

Berdasarkan pada Gambar III.2 di atas, dapat dilihat bahwa penyebaran data berada pada sekitar garis diagonal dan mengikuti garis arah diagonal. Pengujian normalitas juga diperkuat oleh nilai KolmogogorovSmirnov Test yang dapat dilihat pada lampiran 3 yaitu tabel One-Sample Kolmogorov-Smirnov Test. Dari tabel tersebut dapat dilihat bahwa nilai Kolmogorov-Smirnov Z sebesar 0.984dan nilai asymp.Sig. (2-tailed)

\section{cc) (7)(2)}

JURNAL WIDYA This work is licensed under a Creative Commons Attribution-NonCommercialShareAlike 4.0 International License. 
0.288>a(0.05), maka nilai residual terstandarisaasi. Dengan demikian maka model regeresi hipotesis ini memenuhi asumsi normalitas.

III.1.4.2. Uji Multikolinearitas

Uji multikolinearitas dilakukan dengan melihat nilai VIF dan tolerance dari hasil pengolahan data. Suatu persamaan dikatakan tidak terdapat multikolinearitas apabila nilai VIF tidak lebih dari 10 dan nilai tolerance tidak di bawah 0,1. Hasil pengujiannya dapat dilihat di Tabel di bawah ini.

\section{Tabel III. 7. Hasil Pengujian Multikolinearitas}

\begin{tabular}{|c|c|c|}
\hline \multirow[b]{2}{*}{ Model } & \multicolumn{2}{|c|}{ Collinearity Statistics } \\
\hline & Tolerance & VIF \\
\hline \multicolumn{3}{|l|}{1 (Constant) } \\
\hline Diklat Teknis & .452 & 2.211 \\
\hline Motivasi & .452 & 2.211 \\
\hline
\end{tabular}

Sumber: Data Penelitian 2018 Diolah.

Dari hasil yang diperoleh terlihat bahwa nilai VIF masih lebih kecil dari 10 dan nilai tolerance masih lebih besar dari 0,1. Dengan ini maka dapat disimpulkan bahwa persamaan regresi berganda ini telah terbebas dari masalah multikolinearitas.

\section{III.1.4.3. Uji Heteroskedastisitas}

Dengan menggunakan metode grafik dapat diambil kesimpulan apabila ada pola tertentu maka akan terjadi heterokedastisitas dan apabila tidak ada pola tertentu maka akan terjadi homokedastisitas. Hasil grafik yang dilakukan dengan perangkat lunak SPSS dapat dilihat di lampiran. Dari grafik atau gambar di lampiran, dapat diambil kesimpulan bahwa tidak didapati adanya heterokedastisitas karena gambar tersebut tidak menunjukkan adanya suatu pola tertentu atau teratur dari titik-titik yang ada. Ini berarti persamaan tersebut telah memenuhi asumsi klasik suatu persamaan berganda dengan telah dipenuhinya asumsi dasar bahwa variasi residual sama untuk semua pengamatan telah terpenuhi. 
Volume 1, Nomor 1, April 2020: halaman 8-29

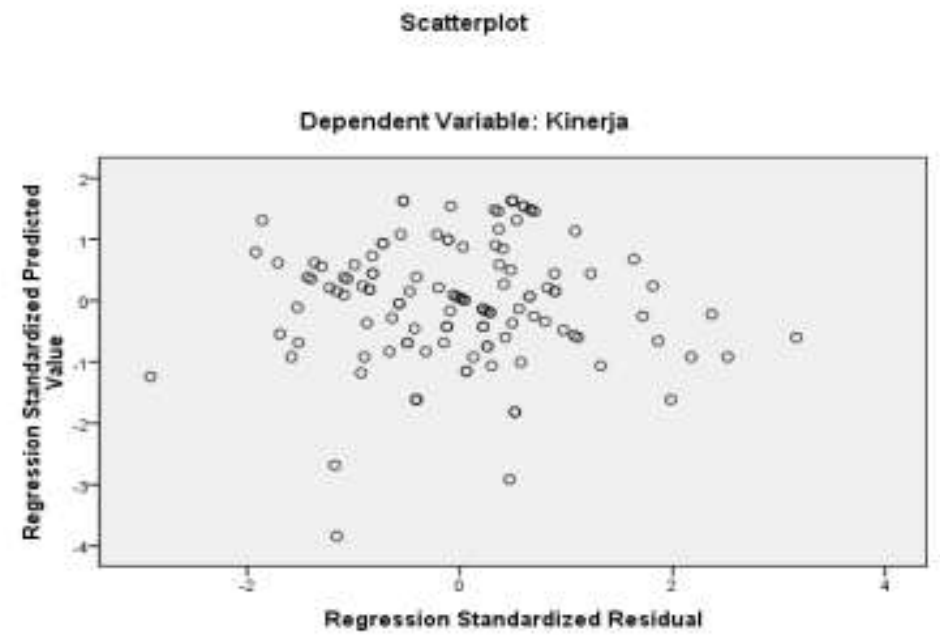

Sumber: Data Penelitian 2018 Diolah.

\section{Gambar III.3. Hasil Pengujian Heteroskedastisitas Secara Grafik}

\section{III.2. Hasil dan Pembahasan}

\section{III.2.1. Hasil Persamaan Regresi}

Hipotesis menyatakan bahwa diklat teknis (X1) serta motivasi (X2) berpengaruh terhadap kinerja alumni Balai Diklat Industri Medan.

\section{Tabel III.8. Hasil Uji Koefisien Regresi Coefficients $^{\mathrm{a}}$}

\begin{tabular}{lccc}
\hline & \multicolumn{2}{c}{ Unstandardized Coefficients } & Standardized Coefficients \\
\cline { 2 - 4 } Model & B & Std. Error & Beta \\
\hline 1 (Constant) & 5.160 & 1.751 & \\
Diklat Teknis & .305 & .087 & .303 \\
Motivasi & .507 & .084 & .518 \\
\hline
\end{tabular}

a. Dependent Variable:

Kinerja

Sumber: Hasil Penelitian, 2018 Diolah.

Berdasarkan pada Tabel III.8 di atas maka persamaa regresi linier berganda dalam penelitian ini adalah:

\section{(c) (1)(2)}

JURNAL WIDYA This work is licensed under a Creative Commons Attribution-NonCommercialShareAlike 4.0 International License. 


$$
Y=5,160+0,305 X 1+0,507 X 2+e
$$

Pada persamaan tersebur dapat dilihat bahwa Diklat teknis (X1), serta Motivasi (X2) memiliki kemampuan untuk mempengaruhi kinerja pegawai (Y) para alumni Balai Diklat Industri Medan. Diklat teknis (X1) dan motivasi (Y2) mempunyai koefisien regresi positif yang membuktikan kontribusinya terhadap kinerja alumni (Y).

Artinya semakin baik pelaksanaan diklat teknis maka akan semakin baik atau semakin meningkat pula kinerja para alumni. Demikian pula dengan motivasi, semakin baik motivasi dari para pegawai maka kinerja para pegawai juga akan semakin baik.

Diklat teknis merupakan usaha untuk memperbaiki kinerja pegawai pada suatu pekerjaan tertentu yang sedang menjadi tanggung jawabnya. Supaya efektif, diklat teknis biasanya harus mencakup pengalaman belajar, aktivitas-aktivitas yang terencana, dan di desain sebagai jawaban atas kebutuhan-kebutuhan yang berhasil diidentifikasi. Secara ideal diklat teknis harus didesain untuk mewujudkan tujuan-tujuan organisasi, yang waktu bersamaan juga mewujudkan tujuan-tujuan dari pegawai secara perseorangan. Jadi Diklat teknis bermanfaat dalam situasi dimana para pegawai kekurangan kecakapan dan pengetahuan. Kegiatan ini sebagai sarana yang ditujukan pada upaya untuk lebih mengaktivkan kerja para pegawai yang kurang aktiv sebelumnya, mengurangi dampak-dampak negativ yang dikarenakan kurangnya pendidikan dan pengalaman yang terbatas, atau kurangnya kepercayaan diri pegawai dalam melaksanakan pekerjaannya Pengukuran motivasi kerja dapat diketahui dengan melakukan survei dalam mendiagnosis bidang masalah tertentu kepada karyawan, sebagai contoh, kuessioner diberikan guna mengumpulkan ide untuk memperbaiki sistem penghargaan kinerja atau untuk menentukan seberapa puas para karyawan dengan program mereka. Mathis (2006), menyatakan bahwa: salah satu jenis survei yang sering dilakukan oleh banyak organisasi adalah survei sikap (attitude survey) yang berfokus pada perasaan dan keyakinan para karyawan tentang pekerjaannya dan organisasi. Dengan berfungsi sebagai cara untuk mendapatkan data tentang cara para karyawan memandang pekerjaan, supervisor mereka, rekan kerja mereka, kebijakan dan praktik organisasional, pengembangan dan jaminan terhadap karyawan serta lingkungan pekerjaan mereka. ini dapat menjadi awal mula untuk meningkatkan motivasi kerja para pegawai, namun apabila penegtahuan dan motivasi mereka turun maka kinerja juga akan ikut turun

\section{III.2.2. Nilai Koefisien Determinasi}

Nilai koefisien determinasi $\left(\mathrm{R}^{2}\right)$ dipergunakan untuk mengukur besarnya pengaruh variabel bebas diklat teknis (X1), serta motivasi (X2) terhadap kinerja alumni Balai Diklat Industri Medan.

Tabel III.9. Hasil Koefisien Determinasi Hipotesis

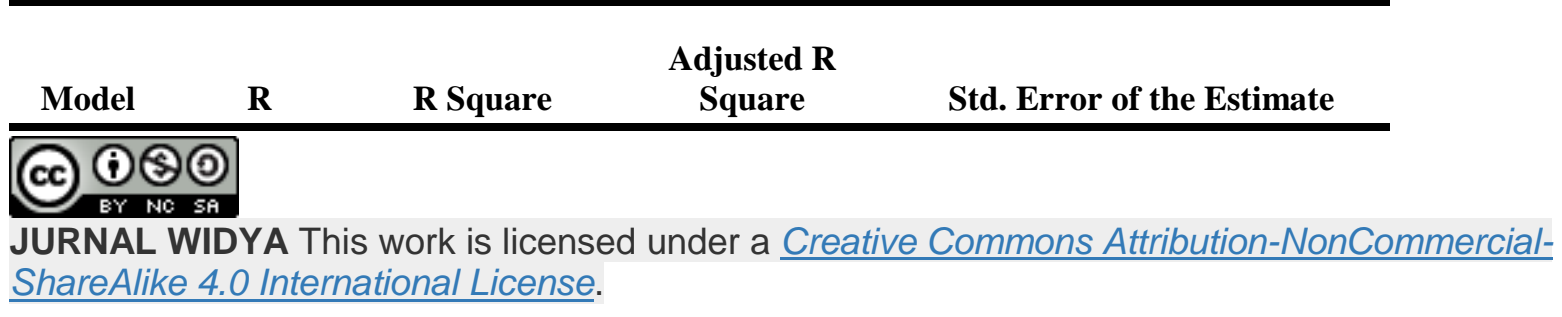




\begin{tabular}{lllll}
\hline 1 & $.770^{\mathrm{a}}$ & .593 & .586 & 2.92713 \\
\hline
\end{tabular}

a. Predictors: (Constant), Motivasi, Diklat Teknis

b. Dependent Variable: Kinerja

Sumber: Data Penelitian 2018 Diolah.

Berdasarkan Tabel III.9 diperoleh nilai koefisien determinasi sebesar 0,593. Hal ini menunjukkan bahwa 59,3\% variabel diklat teknis (X1), serta motivasi (X2) menjelaskan terhadap variabel kinerja alumni Balai Diklat Industri Medan (Y), sedangkan 40,7\% adalah merupakan pengaruh dari variabel bebas lainnya yang tidak dimasukkan dalam penelitian ini.

\section{III.2.3. Uji Hipotesis}

Pada bagian sebelumnya telah diuji asumsi klasik pada suatu persamaan atau regresi dan telah diperoleh hasil dimana regresi berganda yang telah diestimasi telah memenuhi asumsi-asumsi klasik. Pada bagian selanjutnya akan dilakukan pengujian terhadap hasil regresi yang diperoleh baik secara serempak dengan menggunakan Uji-F dan melakukan pengujian parsial dengan menggunakan Uji-t.

\section{III.2.3.1. Pengujian Hipotesis Secara Serempak}

Hasil pengujian hipotesis secara serempak dapat dilihat pada Tabel III.10 di bawah ini

Tabel III. 10. Hasil Uji F Hipotesis

\begin{tabular}{llcrrrr}
\hline \multicolumn{1}{l}{ Model } & \multicolumn{1}{c}{$\begin{array}{c}\text { Sum of } \\
\text { Squares }\end{array}$} & df & Mean Square & \multicolumn{1}{c}{ F } & \multicolumn{1}{c}{ Sig. } \\
\hline 1 & Regression & 1509.351 & 2 & 754.675 & 88.080 & $.000^{\mathrm{a}}$ \\
& Residual & 1036.738 & 121 & 8.568 & & \\
\cline { 2 - 7 } & Total & 2546.089 & 123 & & & \\
\hline
\end{tabular}

a. Predictors: (Constant), Motivasi, Diklat teknis

b. Dependent Variable: Kinerja

Sumber: Data Penelitian 2018 Diolah.

Berdasarkan Tabel III.10 di atas diperoleh bahwa nilai Fhitung (88.080) lebih besar dibanhdingkan dengan Ftabel $(4,16)$ dan sig $\alpha\left(0,000^{\mathrm{a}}\right)$ lebih kecil dari alpha 5\% (0.05). Hal ini mengindikasikan bahwa hasil penelitian menolak Ho dan menerima Ha. Dengan demikian, secara serempak diklat teknis, serta motivasi berpengaruh terhadap kinerja pegawai alumni Balai Diklat Industri Medan, dengan tingkat pengaruh yang sangat-sangat signifikan, dilihat dari data olahan tersebut di atas. III.2.3.2. Pengujian Hipotesis Secara Parsial

Hasil pengujian hipotesis secara parsial dapat dilihat pada Tabel III.11 di bawah ini:

\section{Tabel III.11. Hasil Uji Parsial Hipotesis}

\section{(i) (2) (2)}

JURNAL WIDYA This work is licensed under a Creative Commons Attribution-NonCommercialShareAlike 4.0 International License. 


\begin{tabular}{lcccccc}
\hline & \multicolumn{2}{c}{$\begin{array}{c}\text { Unstandardized } \\
\text { Coefficients }\end{array}$} & \multicolumn{2}{c}{$\begin{array}{c}\text { Standardized } \\
\text { Coefficients }\end{array}$} & & \\
\cline { 2 - 5 } Model & B & Std. Error & Beta & t & \multicolumn{1}{c}{ Sig. } \\
\hline 1 (Constant) & 5.160 & 1.751 & & 2.947 & .004 \\
\hline Diklat Teknis & .305 & .087 & .303 & 3.516 & .001 \\
\hline Motivasi & .507 & .084 & & .518 & 6.004 & .000 \\
\hline
\end{tabular}

a. Dependent Variable: Kinerja

Sumber: Data Penelitian 2018 Diolah.

Berdasarkan Tabel III.10 di atas diperoleh hasil sebagai berikut:

1. Nilai thitung untuk variabel diklat teknis (3.516) lebih besar dibandingkan dengan nilai ttabel (2.00), atau nilai sig. $t$ untuk variabel diklat teknis (0.001) lebih kecil dari alpha (0.025).

2. Nilai thitung untuk variabel motivasi (6.004) lebih besar dibandingkan dengan nilai ttabel (2.00), atau nilai sig.t untuk variabel motivasi (0.000) lebih kecil dari alpha (0.025).

Berdasarkan hasil yang diperoleh maka menolak Ho dan menerima Ha untuk variabel diklat teknis serta motivasi. Dengan demikian secara parsial diklat teknis dan motivasi berpengaruh terhadap kinerja pegawai alumni Balai Diklat Industri Medan. Dalam hal ini, program diklat teknis bermanfaat dalam meningkatkan kualitas pengetahuan dan ketrampilan yang dimiliki pegawai sebagai bekal untuk menyelesaikan tugas-tugas yang diberikan. Hasil penelitian juga memperlihatkan bahwa motivasi dapat mendorong semangat kerja bagi pegawai. Semangat yang dirasakan pegawai dapat meningkatkan kinerja yang bersangkutan dalam pencapaian tujuan.

\section{KESIMPULAN DAN SARAN}

\section{IV.1. Kesimpulan}

Berdasarkan hasil dan pembahasan hasil penelitian yang telah dipaparkan pada bagian terdahulu maka dapat diambil kesimpulan sebagai berikut:

Pendidikan dan pelatihan teknis serta motivasi secara simultan berpengaruh terhadap peningkatan kinerja alumni Balai Diklat Industri Regional I Medan. Dengan terlaksananya pendidikan dan pelatihan teknis yang baik serta adanya motivasi yang tinggi dari para alumni maka akan didapat kinerja yang meningkat dari para alumni. Berdasarkan pengujian variabel independen secara parsial, variabel pendidkan dan Motivasi pengaruh dalam peningkatan kinerja. Sedangkan variabel motivasi adalah merupakan variabel yang dominan berpengaruh terhadap peningkatan kinerja alumni Balai Diklat Industri Regional I Medan.

\section{IV.2. Saran}

Berdasarkan kesimpulan, maka disarankan sebagai berikut:

Pendidikan dan pelatihan teknis serta motivasi secara simultan berpengaruh terhadap peningkatan kinerja alumni Balai Diklat Industri Regional I Medan, sehingga disarankan agar Balai Diklat Industri Regional I Medan dapat tetapmempertahankan dan mengembangkan diklat teknis kepada para pegawai juga diharapkan para atasan dapat memberikan motivasi kepada para pegawai agar mereka makin dapat meningkatkan kinerjanya, bahkan jika mungkin lebih meningkatkan perhatiannya lagi terutama kepada 
Volume 1, Nomor 1, April 2020: halaman 8-29

variabel yang dominan di dalam meningkatkan kinerja yaitu variabel motivasi. Dengan demikian tujuan dari perusahaan atau kebijakan yang telah ditentukan oleh organisasi secara umum akan dapat dicapai.

\section{DAFTAR PUSTAKA}

[1] Amstrong, M, 2002, Performance Management, Kogan Page Ltd, New York.

[2] Alan Bracha, 2002, Performance Management, PT. SUN, Jakarta.

[3] Bacal,R, 2001, Permormance Management, PT. SUN, Jakarta.

[4] Bambrough, J., 1998. Training Your Staff. Sterling Publishers, New Delhi.

[5] Buchari Zainun, 2000, Manajemen dan Motivasi, Balai Aksara, Jakarta.

[6] Djarwanto P, 2001, Mengenai Beberapa Uji Statistik Dalam Penelitian, Liberty, Yogyakarta.

[7] Filippo, Edwin, Moh.Masud, 1996, Manajemen Personalia, Penerbit Erlangga, Jakarta.

[8] Foster, Bill, dan Karen R.Seeker, 2001, Pembinaan Untuk Meningkatkan Kinerja Karyawan, Penerjemah : Ramlan, PPM, Jakarta.

[9] Gibson, James L, John M.Ivancevich Jr, 2000, Organisasi dan Manajemen; Perilaku Struktur, Proses, alih bahasa Djoerban Wahid, Penerbit Erlangga, Jakarta.

[10] Gomes-Mejia, Luis, David B.Balkin, Robert L.Cardy, 1995, Managing Human Resources, PrenticeHall, Inc.

[11] Hasibuan, SP, Malayu. 2002. Manajemen Sumber Daya MAnusia, Edisi Revisi, Bumi Aksara, Jakarta.

[12] Husein Umar, 2004 Metode Penelitian untuk Skripsi dan Tesis Bisnis, Cetakan ke-6, PT.Raja Grafindo Persada, Jakarta.

[13] Mangkunegara, A.Anwar Prabu, 2001, Manajemen Sumber Daya Manusia Perusahaan, Penerbit PT.Remaja Rosdakarya, Bandung.

[14] Manullang.M, 1998, Dasar-dasar Manajemen, Cetakan ketujuh belas Ghalia Indonesia, Jakarta.

[15] Mahsum Moh, 2006, Pengukuran Kinerja Sektor Publik, BPFE, Yogyakarta

[16] Mathis, L. Robert dan Jackson. H. John, 2001. Manajemen Sumber Daya Manusia, Edisi Pertama, Buku I, Salemba Empat, Jakarta.

[17] Mello, Jeffry.A, 2002, Strategic Human Resource Management, USA: Thomson South-Western.

[18] Mondy.R.Wayne, and Robert M.Noe, 2005, Human Resource Management, Ninth Edition, USA, Mc.Graw-Hill.

[18] Nasution, Harmein, 2000. Proses Pengelolaan Sumber Daya Manusia. Cetakan Pertama. USU Press. Medan.

[19] Nawawi, H. Hadari, 2003, Manajemen Sumber Daya Manusia untuk Bisnis yang Kompetitif, Gajah Mada University Press, Yogyakarta.

[20] Noe, A.Raymond, 1997, Pengembangan Sumber Daya Manusia, alih bahasa Mukaram dan Marwansah, Penerbit Erlangga, Jakarta.

[21] Notoatmodjo.S, 1998, Pengembangan Sumber Daya Manusia, Edisi Revisi, PT. Rieneka Cipta, Jakarta.

[22] Pont, A. 1991. Perilaku Keorganisasian, Dunia Pustaka Jaya, Jakarta.

[23] Rivai, Veithzal dan Ahmad Fawzi Mohd Basri, 2005. Performance Appraisal. Cetakan Pertama, PT Raja Grafindo Persada, Jakarta.

[24] Ruky, 2001, Sistem Manajemen Kinerja, PT. SUN, Jakarta.

[25] Robins, Stephen P, 2003, Perilaku Organisasi, Buku I, Edisi Indonesia, PT.Indeks, Jakarta.

[26] Santoso Budi, Purbayu, dan Ashari, 2002, Analisis Statistik dengan Microsoft Excell \& SPSS, Penerbit Andi, Jakarta. 


\section{Jurnal Widya}

P-ISSN: 2746-5411

Volume 1, Nomor 1, April 2020: halaman 8-29

e-ISSN: $x x x x-x x x x$

https://jurnal.amikwidyaloka.ac.id/index.php/awl

jurnal@amikwidyaloka.ac.id / editor.jurnalwidya@gmail.com

[27] Sayuti, 2006, Motivasi dan Faktor-faktor yang Mempengaruhinya, Penerbit Ghalia Indonesia, Jakarta.

[28] Simamora Henry, 2004, Manajemen Sumber Daya Manusia, STIE-YKPN, Yogyakarta.

[29] Sirait Justine T. 2006, Memahami Aspek-Aspek Pengelolaam Sumber Daya Manusia Dalam Organisasi. Cetakan Pertama, PT Grasindo. Jakarta.

[30] Singarimbun, Masri, dan Efendi, 1995, Metode Penelitian Survey, Cetakan Kedua, PT. Pustaka LP3ES Indonesia, Jakarta.

[31] Suyadi,K, M.Ali Ramdhani, 1999, Sistem Pendukung Keputusan, PT. Remaja Rosdakarya, Bandung.

[32] Sugiyono, 2004, Metode Penelitian Bisnis, Cetakan keenam, Alfabeta, Bandung.

[33] Sulistiani \& Rosida, 2003. Manajemen Sumber Daya Manusia. Penerbit Graha Ilmu, Yogyakarta.

[34] Sofyandi, Herman, 2008, Manajemen Sumber Daya Manusia, Graha Ilmu, Yogyakarta.

[35] Tilaar, H. 1997, Pengembangan Sumber Daya Manusia dalam Era Globalisasi; Visi, Misi dan Program Aksi Pendidikan dan Pelatihan Menuju 2020, PT.Gramedia, Jakarta.

[36] Wahyu Sumidjo, 1996, Kepemimpinan dan Motivasi, Penerbit Ghalia Indonesia, Ciawi-Bogor.

[37] Winardi,J, 2000, Motivasi dan Pemotivasian dalam Manajemen, Penerbit PT.Raja Grafindo Persada, Jakarta.

[38] Werther, William B, and Keith Davis, 1996, Human Resorces and Personal Management, Fifth Edition, Mc.Graw-Hill, USA.

[39] Amin, Budi Astuti, 2006, Kinerja Sebagai Ukuran Keberhasilan, Jurnal Manajemen \& Kewirausahaan Vol. 8, Fakultas Ekonomi, Universitas Kristen Petra.

[40] Agusty, Ferdinand, 2008, Pelatihan Sebagai Motivasi Perubahan, Jurnal Manajemen\&Kewirausahaan Vol. 12, Fakultas Ekonomi, Universitas Kristen Petra.

[41] Tanjung, Bahdin Nur, 2003, Memahami Arti Penting Pelatihan dalam Organisasi, Jurnal Ilmiah Manajemen \& Bisnis Vol.3, Program Studi Manajemen Fakultas Ekonomi Universitas Muhammadiyah Sumatera Utara.

[42] Yulius, Edi, 2008, Analisis Pengaruh Diklat, Kemampuan, Motivasi Kerja dan Budaya Organisasi terhadap Kinerja Aparatur Industri di Daerah Yogyakarta, Tesis.

[43] Peraturan Pemerintah Nomor 101 tahun 2000, tentang Pendidikan dan Pelatihan Pegawai Negeri Sipil. 